\title{
Root growth dynamics and productivity of quinoa (Chenopodium quinoa Willd.) in response to fertilization and soil tillage
}

\author{
Ioanna P. Kakabouki ${ }^{1}$, Ioannis Roussis ${ }^{1}$, Dimitra Hela ${ }^{2}$, \\ Panayiota Papastylianou ${ }^{1}$, Antigolena Folina ${ }^{1}$, Dimitrios Bilalis ${ }^{1 *}$ \\ ${ }^{1}$ Laboratory of Agronomy, Department of Crop Science, School of Agriculture, Engineering and Environmental \\ Sciences, Agricultural University of Athens, 75, Iera Odos Str., 11855 Athens, Greece \\ ${ }^{2}$ Department of Chemistry, School of Sciences, University of Ioannina, 45110 Ioannina, Greece
}

\begin{abstract}
Quinoa is a gluten-free pseudocereal crop recognized for its exceptional nutritional properties. A 3-year field experiment was conducted to evaluate the influence of soil tillage and fertilization on root growth and productivity of quinoa. The experiment was laid out in a split-plot design with two replicates, two main plots [conventional (CT) and minimum tillage (MT)] and four sub-plots [fertilization treatments: untreated, inorganic fertilization with 100 (N1) and $200 \mathrm{~kg} \mathrm{~N}^{-1}(\mathrm{~N} 2)$, and sheep manure]. Mean weight diameter (MWD) of soil aggregates, total porosity, organic matter and soil total nitrogen increased with the longterm fertilization with sheep manure. The major part of the roots (approximately 70\%) is concentrated in the 0-30 cm soil layer. Root length density increased with increased rate of applied nitrogen, and a higher value $\left(1.172 \mathrm{~cm} \mathrm{~cm}^{-3}\right)$ was found in $\mathrm{N} 2$ plots. Additionally, higher root mass density $\left(1.114 \mathrm{mg} \mathrm{cm}^{-3}\right)$ was observed under MT. Plant height and dry weight were clearly affected by fertilization, with higher values obtained in N2 plots. Moreover, it was observed that quinoa cultivated under CT and N2 treatment produced a higher seed yield $\left(2595 \mathrm{~kg} \mathrm{ha}^{-1}\right)$. As a conclusion, increasing the levels of applied nitrogen up to $200 \mathrm{~kg} \mathrm{~N} \mathrm{ha}^{-1}$ improves root growth and consequently the yields of quinoa.
\end{abstract}

Key words: conventional tillage, nitrogen fertilization, root length density, root mass density, yield

\section{INTRODUCTION}

Quinoa (Chenopodium quinoa Willd., Family: Amaranthaceae) is a pseudocereal crop that has traditionally been cultivated in the Andean highlands of Bolivia, Peru and Ecuador for more than 7000 years, supplying highly nutritious food to poor farmers in the Andes (Jacobsen, 2003). It is considered as a multipurpose agricultural crop. Its grains may be utilized for human consumption and animal feeding due to their remarkable nutritional properties (Bhargava et al., 2006). The high nutritional value of the seeds is mainly due to the gluten-free and high-protein content (about 14.6\%) with an abundance of essential amino acids, particularly lysine, methionine and threonine, which in cereals are deficient (Bhargava et al., 2006). The whole plant has been used as green fodder to feed livestock, including cattle, pigs and poultry (Kakabouki et al., 2014). In addition, quinoa is characterized by exceptional

*Corresponding author. 
environmental adaption, with natural tolerance to drought, salinity, frost and other abiotic and biotic factors, making it suitable for several agricultural systems (Jacobsen, 2003; Gonzalez et al., 2012). Because of quinoa's stress-tolerance characteristics and exceptional nutritional properties, the interest in the crop is globally increasing. The Food and Agriculture Organization of the United Nations (FAO) has already recognized quinoa as one of the crops that are destined to offer food security in the 21st century and declared the year 2013 as the year of quinoa (Kakabouki et al., 2014).

The knowledge of factors that influence root development is important for improving nutrient cycling in soil-plant systems. Roots play a fundamental role in suppling water, nutrients and hormones and giving mechanical support to crop plants (Merrill et al., 2002). In addition, the amounts of $\mathrm{C}$ and $\mathrm{N}$ supplied by roots can contribute to the improvement of soil organic matter (Sainju et al., 2005). The contribution of the root system to total plant weight is nearly $10-20 \%$, and a welldeveloped root system is indispensable for healthy plant growth and development. Root growth is genetically dependent, but it is also influenced by various chemical, physical and biological factors, especially those parameters that are closely correlated with the availability of oxygen and water to the roots and any kind of mechanical impedance that roots face during the growth period (Sainju et al., 2005).

Mineral nutrition constitutes a significant factor influencing the growth of plant roots, although detailed information on nutritional effects is limited, mainly because roots are half-hidden organs that are very difficult to separate from the soil (Gregory, 1994). The influence of fertilization on root growth is similar to that on shoot growth; however, the magnitude of the influence may differ. In soils with sufficient nutrients there are more root hairs than in those without nutrients, and the root system is mostly developed in the top layer of soil (Gregory, 1994). In crop plants, root and shoot growth occur in an apparent coordinated fashion and thus their activities are reciprocally dependent (Goss and Kay, 2005). When a large amount of nutrients is supplied to the leaves through the root system, photosynthesis remains high during maturation, which ensures a sufficient amount of carbohydrates in the roots (Osaki et al., 1997). Deficiencies of mineral elements affect plant growth and root-shoot relationships. Nitrogen is one of the most consequential nutrients in crop production and a deficiency of it in crop plants profoundly influences plant growth, development and yield. The use of nitrogen fertilizer increases root growth in soils having a low organic matter content (Gregory, 1994). In general, nitrogen fertilization can promote root growth by increasing soil nitrogen availability (Garton and Widders, 1990) and enhancing crop performance and nitrogen use efficiency (Kakabouki et al., 2018). Moreover, nitrogen improves the production of lateral roots and root hairs, as well as increasing root length density deep in the soil profile (Hansson and Andren, 1987).

Soil tillage is among the main elements that can affect the physical and chemical properties of soil and therefore can make differences in plant establishment, root growth, aerial cover and eventually crop yield. Reducing tillage positively affects several soil properties whereas excessive and unnecessary tillage operations give rise to opposite phenomena which are harmful to the soil. Minimum (reduced) tillage improves the soil structure, increases soil organic matter content and the proportion of larger aggregates, and reduces soil bulk density (Lal, 1989; Daraghmeh et al., 2009). Bilalis et al. (2012) reported that the highest soil porosity, soil total nitrogen and root density of quinoa crops were observed in soils subjected to a minimum tillage system.

Limited data are available regarding the influence of soil tillage and fertilization on root growth dynamics and growth performance of quinoa under Mediterranean semi-arid conditions. Therefore, the objective of this study was to investigate the effects of tillage system and fertilizer type on the dynamics of root system development and productivity of quinoa crops.

\section{MATERIAL AND METHODS}

\section{Site description and experimental design}

A 3-year field experiment was carried out in Western Greece (Agrinio region, Latitude: $38^{\circ} 35^{\prime}$ N, Longitude: $21^{\circ} 25^{\prime} \mathrm{E}$ ) from 2011 to 2013 . The soil was a silt loam ( $24.9 \%$ clay, $61.2 \%$ silt, $13.9 \%$ sand) with $\mathrm{pH}\left(1: 2 \mathrm{H}_{2} \mathrm{O}\right) 7.4$, EC $0.63 \mathrm{mS} \mathrm{cm}{ }^{-1}, 0.152 \%$ total nitrogen, a sufficient supply of phosphorus (P Olsen: $175 \mathrm{mg} \mathrm{kg}^{-1}$ soil) and potassium (632 $\mathrm{mg} \mathrm{kg}^{-1}$ soil), and $1.45 \%$ organic matter content. The site was managed according to organic agriculture guidelines (EC 834/2007). Mean values of meteorological data concerning air temperature and precipitation on the experimental 


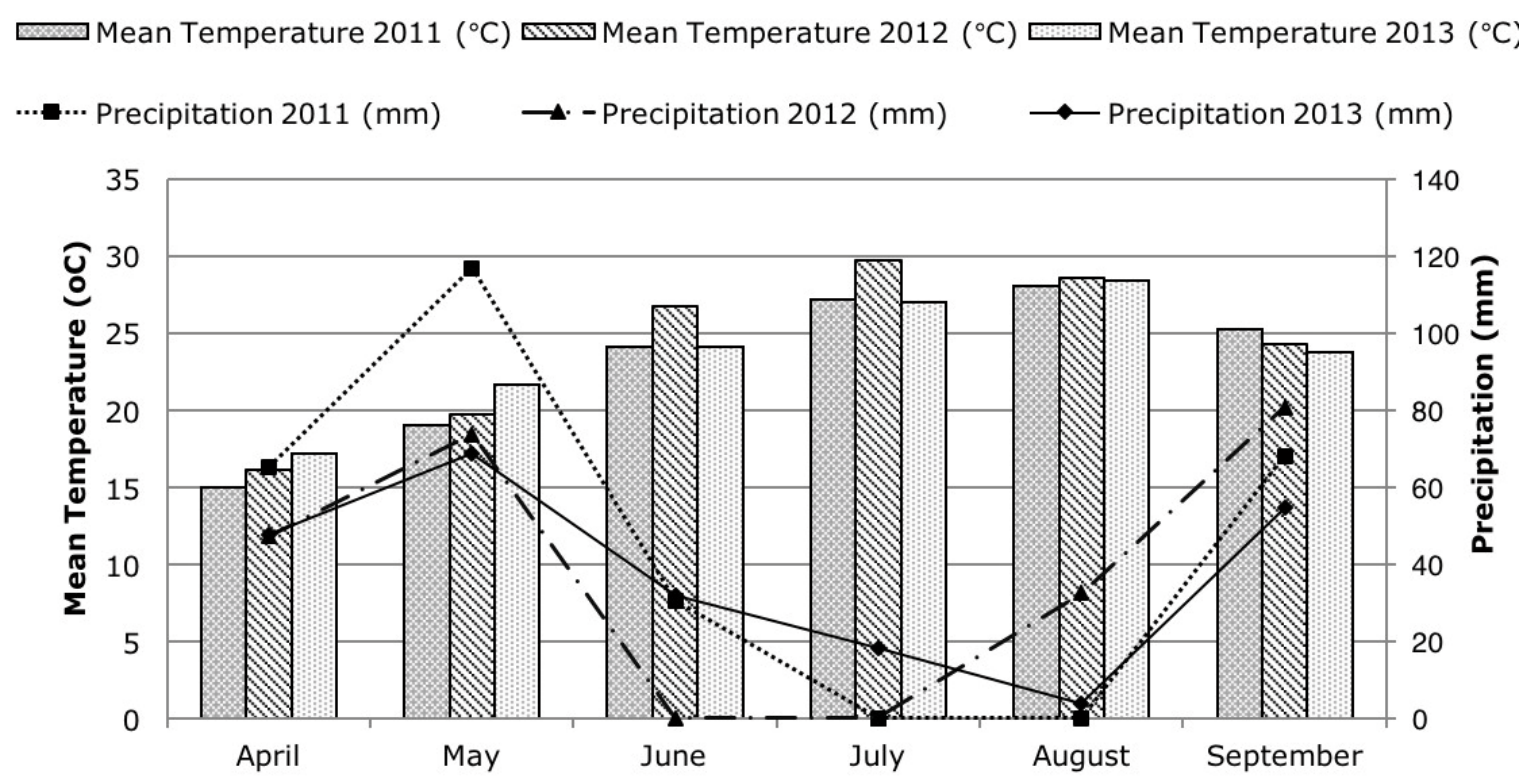

Figure 1. Mean monthly air temperature and precipitation for the experimental site during the experimental periods (April-September, 2011, 2012 and 2013)

site for the three years are presented in Figure 1. The mean air temperature showed no significant differences across the three cultivation periods of the experiment. The same was also valid for the average precipitation. However, there was a high rainfall $(116.8 \mathrm{~mm})$ in May 2011 resulting in a lower application of irrigation in 2011.

The experiment was set up on an area of $850 \mathrm{~m}^{2}$ according to the split plot design with two replicates, two main plots and four sub-plots. The main plots were conventional (CT) and minimum tillage (MT). CT was achieved by mouldboard ploughing at $25 \mathrm{~cm}$, followed by one-pass rotary hoeing at 10-15 cm, while MT was achieved by chiselling to a depth of $25 \mathrm{~cm}$ followed by chiselling down to $10-15 \mathrm{~cm}$. Four fertilizer treatment sub-plots included the control (untreated), inorganic nitrogen (fertilizer 26-0-0) with $100 \mathrm{~kg} \mathrm{~N} \mathrm{ha}^{-1}$ (N1), inorganic nitrogen with $200 \mathrm{~kg} \mathrm{~N} \mathrm{ha}^{-1}$ (N2), and sheep manure $\left(3000 \mathrm{~kg} \mathrm{ha}^{-1}\right.$, solid, $\left.11.52 \% \mathrm{~N}\right)$. The fertilizers were applied as basal fertilization. The main and subplot sizes were $200 \mathrm{~m}^{2}$ and $50 \mathrm{~m}^{2}$, respectively. Quinoa (Chenopodium quinoa Willd. cv. Faro) was sown by hand in rows $30 \mathrm{~cm}$ apart at a depth of $2-3 \mathrm{~cm}$ and approximate density of 250,000 plants $\mathrm{ha}^{-1}$. The field was sown on 6th April 2011, 5th April 2012 and 10th April 2013. An overhead sprinkler system was also set up in the field. The field area was irrigated 4 times in 2011 and 5 times in 2012 and 2013. The total quantity of water applied during the cultivation periods was 230,250 and $250 \mathrm{~mm}$ in 2011, 2012 and 2013, respectively. Throughout the experimental period, there was no incidence of pest or disease on the quinoa crops. Finally, weeds were controlled by hand hoeing when it was necessary.

\section{Sampling, measurements and methods}

Mean weight diameter (MWD) of soil aggregates was determined by using the oscillation apparatus Analysette 3 (Spartan, Fritsch Ltd., Oberstein, Germany) at 100 days after sowing (DAS). The oscillation time was 4 min., using $2 \mathrm{~kg}$ of air-dried soil from a depth of 0 to $60 \mathrm{~cm}$ and sieve mesh sizes of 20 to 40,10 to 20,5 to 10,2 to 5 and $<2$ $\mathrm{mm}$. The MWD equals the sum of the products of mean diameter, $x_{i}$, of each size fraction and the proportional weight, $w_{i}$, of the corresponding size fraction, and it was calculated using the equation given by Van Bavel (1949):

$$
M W D=\sum_{i=1}^{n} x_{i} w_{i}
$$

where:

$x_{i}$ - the mean diameter of each size fraction/size class midpoint,

$w_{i}$ - the proposition of the total sample weight occurring in the corresponding size fraction.

The total porosity $(\mathrm{St})$ of soil was estimated from the following equation (Flint and Flint, 2002):

$$
S t(\%)=(1-D b / D p)
$$

where:

$S t$ - total pore spaces,

$D p$ - particle density $\left(2.5 \mathrm{~g} \mathrm{~cm}^{-3}\right)$,

$D b-$ soil bulk density. 
For each plot, soil bulk density was determined by taking undisturbed soil cores with $100 \mathrm{~cm}^{3}$ cylinders from a depth of $0-10 \mathrm{~cm}$. Three samples of $100 \mathrm{~cm}^{3}$ per plot were taken at 100 DAS. The undisturbed samples were finally oven-dried at $100^{\circ} \mathrm{C}$ for $24 \mathrm{~h}$ to obtain soil dry mass and the soil bulk density was calculated as follows:

$$
D b=\text { dry mass }(g) / 100 \mathrm{~cm}^{3}
$$

The soil total nitrogen was determined by the Kjeldahl method, using a Buchi 316 device in order to combust and extract the soil sample.

For the determination of plant dry weight, height and LAI (100 DAS), 10 plants were randomly selected from each plot. Dry weight was determined after drying for $48 \mathrm{~h}$ at $65^{\circ} \mathrm{C}$. Leaf area was measured using an automatic leaf area meter (Delta-T Devices Ltd, Burwell, Cambridge, UK). Thus, the measurements on per plant basis were converted into a LAI by dividing the readings by the average crop density of each plot.

Root samples were collected from the $0-30 \mathrm{~cm}$ and 30-60 $\mathrm{cm}$ layers by using a cylindrical auger (25 cm length, $10 \mathrm{~cm}$ diameter) at the midpoint between successive plants within a row. Three samples were analyzed per layer per plot at 25 , $50,75,100,125$ and 150 DAS. The corresponding growth stages according to the extended $\mathrm{BBCH}$ Scale were 12 (second pair of leaves visible), 21 (one side shoot visible), 60 (beginning of anthesis), 70 (fruit set), 81 (milky grain) and 89 (ripe grain) (Sosa-Zuniga et al., 2017). For each sample, the roots were separated from the soil after being soaked in a solution of water $+\left(\mathrm{NaPO}_{3}\right)_{6}+\mathrm{Na}_{2} \mathrm{CO}_{3}$ for $24 \mathrm{~h}$ and then decanted into a $0.1 \%$ trypan blue FAA staining solution (a mixture of $10 \%$ formalin, $50 \%$ ethanol and 5\% acetic acid solutions). For the determination of root length density (RLD), the root samples were placed on a high-resolution scanner (Epson Perfection V330 Photo; Seiko Epson Corp., Nagano-ken, Japan) using DT software (Delta-T Scan version 2.04; Delta-T Devices Ltd, Burwell, Cambridge, UK) (Kokko et al., 1993). The root mass density (RMD) was determined after drying for $48 \mathrm{~h}$ at $70^{\circ} \mathrm{C}$. Moreover, quinoa seed yield was determined by using plants from the middle subplot area $\left(10 \mathrm{~m}^{2}\right)$ in the middle of September.

\section{Statistical analysis}

The experimental data were subjected to statistical analysis using the SigmaPlot 12 statistical software (Systat Software Inc., San Jose, CA, USA). The parameter values produced by the tillage systems and fertilization treatments in the three years were analyzed adopting a $3 \times 2 \times 4$ factorial design (three years, two tillage systems and four fertilization treatments) laid out in a split-plot design with two replications. The analysis of variance (ANOVA) used a mixed model, with the years and replications as random effects and the tillage system and fertilization as fixed effects. Differences between means were separated using Tukey's test. Correlation analyses were used to describe the relationships between the growth parameters and yield components using Pearson's correlation. All comparisons were made at $p=0.05$ level of significance.

\section{RESULTS AND DISCUSSION}

\section{Mean weight diameter (MWD) of soil aggregates}

The mean weight diameter(MWD) of soil aggregates is a parameter describing the quality of soil structure and belongs to the physical soil properties. The influence of the tillage system and fertilization on MWD of soil aggregates is shown in Table 1. MWD was not influenced by the tillage system during the experimental periods; however, the highest values (8.44-8.68 $\mathrm{mm}$ ) were recorded in the soils subjected to the conventional tillage system, while the lowest values (8.18-8.24 mm) were obtained from minimum tillage. Concerning the effect of fertilization, MWD did not differ among the different fertilization treatments during the first year (2011) of the experiment, but significant differences were found during the last two years, where the highest values (8.15-8.31 and 9.01-9.05 $\mathrm{mm}$ for 2012 and 2013, respectively) were found under manure fertilization. The application of manure improved soil physical properties through increased soil aggregation, improved aggregate stability and decreased the volume of micropores while increasing macropores (Zhang and Fang, 2007).

\section{Total porosity}

Total porosity belongs to the most important physical soil properties and is associated with the development of the root system and the infiltration of water and nitrates. The analysis of variance revealed that total porosity was not affected by soil tillage. Despite that, the highest values were obtained in the plots subjected to minimum tillage during the experimental periods (Tab. 1). Earlier studies had shown that the adoption of a minimum tillage system led to the improvement of soil properties such as organic matter, total porosity and total nitrogen (Bilalis et al., 2010, 2012). Total porosity was only influenced by fertilization. 
Table 1. Effects of tillage systems (conventional and minimum tillage: CT and MT, respectively) and fertilization (control, inorganic fertilization $100 \mathrm{~kg} \mathrm{~N} \mathrm{ha}^{-1}(\mathrm{~N} 1)$, inorganic fertilization $200 \mathrm{~kg} \mathrm{~N} \mathrm{ha}^{-1}$ (N2) and sheep manure) on mean weight diameter $(\mathrm{mm})$, soil total porosity $(\%)$, soil organic matter $(\% \mathrm{C})$ and soil total nitrogen $(\% \mathrm{~N})$ of quinoa crops

\begin{tabular}{|c|c|c|c|c|c|c|c|c|}
\hline \multirow[b]{2}{*}{ Fertilization } & \multicolumn{8}{|c|}{ Tillage system } \\
\hline & $\mathrm{CT}$ & MT & $\mathrm{CT}$ & MT & $\mathrm{CT}$ & MT & $\mathrm{CT}$ & MT \\
\hline 2011 & \multicolumn{2}{|c|}{ MWD (mm) } & \multicolumn{2}{|c|}{ Total porosity (\%) } & \multicolumn{2}{|c|}{ Organic matter $(\%)$} & \multicolumn{2}{|c|}{ Total nitrogen $(\% \mathrm{~N})$} \\
\hline Control & 7.95 & 8.34 & 41.3 & 38.9 & 1.95 & 1.88 & 0.140 & 0.133 \\
\hline N1 & 8.08 & 8.52 & 43.9 & 46.4 & 2.11 & 1.90 & 0.157 & 0.141 \\
\hline $\mathrm{N} 2$ & 8.19 & 8.86 & 42.3 & 44.7 & 2.03 & 1.90 & 0.166 & 0.147 \\
\hline Manure & 8.48 & 8.94 & 46.8 & 47.6 & 2.26 & 2.00 & 0.167 & 0.146 \\
\hline $\mathrm{F}_{\text {tillage }}$ & \multicolumn{2}{|c|}{$3.72^{\mathrm{ns}}$} & \multicolumn{2}{|c|}{$0.49^{\text {ns }}$} & \multicolumn{2}{|c|}{$3.81^{\mathrm{ns}}$} & \multicolumn{2}{|c|}{$\begin{array}{c}9.07 * \\
(\text { Tukey }=0.013)\end{array}$} \\
\hline $\mathrm{F}_{\text {fertilization }}$ & \multicolumn{2}{|c|}{$0.94^{\mathrm{ns}}$} & \multicolumn{2}{|c|}{$\begin{array}{c}6.80 * \\
(\text { Tukey }=3.46)\end{array}$} & \multicolumn{2}{|c|}{$1.14^{\mathrm{ns}}$} & \multicolumn{2}{|c|}{$3.03^{\mathrm{ns}}$} \\
\hline $\mathrm{F}_{\text {tillage }} \times$ fertilization & \multicolumn{2}{|c|}{$0.04^{\mathrm{ns}}$} & \multicolumn{2}{|c|}{$0.94^{\mathrm{ns}}$} & \multicolumn{2}{|c|}{$0.22^{\mathrm{ns}}$} & \multicolumn{2}{|c|}{$0.36^{\mathrm{ns}}$} \\
\hline 2012 & \multicolumn{2}{|c|}{ MWD (mm) } & \multicolumn{2}{|c|}{ Total porosity (\%) } & \multicolumn{2}{|c|}{ Organic matter (\%) } & \multicolumn{2}{|c|}{ Total nitrogen $(\% \mathrm{~N})$} \\
\hline Control & 7.61 & 7.52 & 40.3 & 42.3 & 1.78 & 1.62 & 0.132 & 0.134 \\
\hline N1 & 7.35 & 7.64 & 43.8 & 46.1 & 1.97 & 1.70 & 0.144 & 0.131 \\
\hline N2 & 7.20 & 7.73 & 42.2 & 43.9 & 1.89 & 1.62 & 0.149 & 0.127 \\
\hline Manure & 8.15 & 8.31 & 46.2 & 47.7 & 2.69 & 2.51 & 0.172 & 0.195 \\
\hline $\mathrm{F}_{\text {tillage }}$ & \multicolumn{2}{|c|}{$3.96^{\mathrm{ns}}$} & \multicolumn{2}{|c|}{$1.31^{\mathrm{ns}}$} & \multicolumn{2}{|c|}{$\begin{array}{c}10.76^{*} \\
(\text { Tukey }=0.433)\end{array}$} & \multicolumn{2}{|c|}{$0.13^{\mathrm{ns}}$} \\
\hline $\mathrm{F}_{\text {fertilization }}$ & \multicolumn{2}{|c|}{$\begin{array}{c}8.69 * * \\
(\text { Tukey }=0.249)\end{array}$} & \multicolumn{2}{|c|}{$2.27^{\mathrm{ns}}$} & \multicolumn{2}{|c|}{$\begin{array}{c}39.47 * * * \\
(\text { Tukey }=0.357)\end{array}$} & \multicolumn{2}{|c|}{$\begin{array}{c}16.48 * * * \\
(\text { Tukey }=0.029)\end{array}$} \\
\hline $\mathrm{F}_{\text {tillage } \times \text { fertilization }}$ & \multicolumn{2}{|c|}{$0.03^{\text {ns }}$} & \multicolumn{2}{|c|}{$0.01^{\mathrm{ns}}$} & & & & \\
\hline 2013 & MV & m) & Total & ty $(\%)$ & Organi & $\operatorname{ter}(\%)$ & Total 1 & $(\% \mathrm{~N})$ \\
\hline$\overline{\text { Control }}$ & 7.47 & 7.64 & 38.0 & 40.1 & 1.64 & 1.59 & 0.133 & 0.141 \\
\hline N1 & 7.63 & 8.35 & 44.5 & 45.9 & 1.78 & 1.55 & 0.140 & 0.153 \\
\hline N2 & 8.70 & 8.73 & 41.1 & 43.6 & 1.90 & 1.50 & 0.134 & 0.126 \\
\hline Manure & 9.01 & 9.05 & 46.2 & 47.8 & 2.69 & 2.53 & 0.192 & 0.191 \\
\hline $\mathrm{F}_{\text {tillage }}$ & & & & & (Tuke & $.491)$ & & \\
\hline $\mathrm{F}_{\text {fertilization }}$ & (Tuk & $433)$ & (Tu & $4.63)$ & $\begin{array}{r}44 \\
\text { (Tuke }\end{array}$ & $* 384)$ & (Tul & 027) \\
\hline$F_{\text {tillage }} \times$ fertilization & & & & & & & & \\
\hline
\end{tabular}

F-test ratios are from ANOVA. Significant at $* * *$ and $* * *$ indicate significance at $p=0.05,0.01$ and 0.001 , respectively, and ns: not significant. The Tukey's test $(p=0.05)$ values for tillage system and fertilization are also presented

Specifically, the highest total porosity values (46.9$47.3 \%$ ) were generally observed in the case of the treatment with manure and were $4-10 \%$ higher than in the inorganic treatments. Amgain and Singh (2001) had observed that the continuous use of chemical fertilizers increased soil bulk density and mechanical impedance, and decreased soil porosity. In addition, Pagliai et al. (2004) found that the application of manure improved soil porosity and soil aggregation.

\section{Organic matter}

Organic matter is a chemical and biological property of the soil and constitutes a primary nutrient pool of organic nitrogen and a substrate for microbial activity. As shown in Table 1, during the second (2012) and third (2013) year of the experiment, the organic matter content of soil was significantly affected by both tillage and fertilization. The soils subjected to the minimum tillage presented lower values (1.79 and 1.89\% for 2012 and 2013, respectively) than the conventionally tilled ones (2.00 and $2.08 \%$ for 2012 and 2013, respectively). The lowest values observed under the minimum tillage were probably due to the non-incorporation of plant residues into the soil. The fertilization with manure gradually increased the levels of organic matter during the experimental periods, with the highest value (2.61\%) obtained in the third year. Contrariwise, the application of inorganic fertilizers tended to decrease the soil organic matter content in the course of time. As reported by Varvel and Wilhelm (2010), the application of organic fertilizers led to a higher soil organic 
content compared to the application of the same amount of inorganic fertilizers.

\section{Soil total nitrogen}

Soil total nitrogen is identified as a factor which is important to soil fertility in both managed and natural ecosystems (Kucharik et al., 2001), and can reflect the soil nitrogen status. It is a component of organic matter and its levels are increased by organic fertilization. According to the combined analysis of variance and Table 1, fertilization had only a significant effect on total nitrogen. With the exception of the first year (2011), the total nitrogen was significantly higher in the treatments with manure, and the values were 0.183 and 0.192 for the years 2012 and 2013, respectively. Because of the long-term fertilization with manure, the final rates of total nitrogen in the soil were increased by $20-25 \%$ compared to the first year (2011) of the study. In addition, the cumulative application of manure resulted in the removal of the negative effects of conventional tillage on total nitrogen, as demonstrated by the combined analysis (Tab. 4). A similar trend has been reported by Meng et al. (2005).

\section{Root length density (RLD) and root mass density (RMD)}

Crops can accumulate the products of photosynthesis in their leaves, stems, seeds as well as roots, and the development of robust root systems is essential to produce increased crop yields. A well-developed root system is needed to absorb adequate amounts of water and nutrients, especially under conditions of biotic or abiotic stress. Root growth and distribution constitute important characteristics for the absorption of water and nutrients from the soil profile (Costa et al., 2002; Fageria and dos Santos, 2013). In the present study, root growth, measured as root length density (RLD), increased in a sigmoidal fashion (Fig. 2A) with the advancement of plant age. During the first 50 days after sowing, the development of the root system was slow. A rapid root growth rate was observed before the beginning of anthesis (75 DAS), which corresponded to the plant transition between vegetative and reproductive growth, and then, the root growth increased almost linearly until the end of anthesis and the beginning of fruit development. Root length density (RLD) did not differ between the two tillage systems during the first (2011) and third (2013) year of the experiment, but significant differences were observed in 2012 (second year of experiment), especially at 100 DAS, where the higher values $\left(0.778-1.103 \mathrm{~cm} \mathrm{~cm}^{-3}\right.$ for $0-30$ $\mathrm{cm}$ depth) were observed under minimum tillage (Tabs 2A, 2B, 2C). With the exception of the first year (2011), root length density was significantly affected by fertilization. The highest root length density (RLD) was achieved in the N2 treatment at 100 DAS. In 2012, the values were 0.971-0.972 and $0.422-0.430 \mathrm{~cm} \mathrm{~cm}^{-3}$ for $0-30$ and $30-60 \mathrm{~cm}$ depth, while, during the third year (2013), the values were 1.114-1.229 and $0.514-0.526 \mathrm{~cm} \mathrm{~cm}^{-3}$ for $0-30$ and $30-60 \mathrm{~cm}$ depth, respectively. Root length density (RLD) either plateaued or declined until harvest (physiological maturity).

Root mass density (RMD) also followed the same trend as root length density, presenting a corresponding sigmoidal fashion (Fig. 2B) with the advancement of plant age from 25 to 150 days. The slow increase in root mass density early in the growth cycle of plant (25-50 DAS) is highly

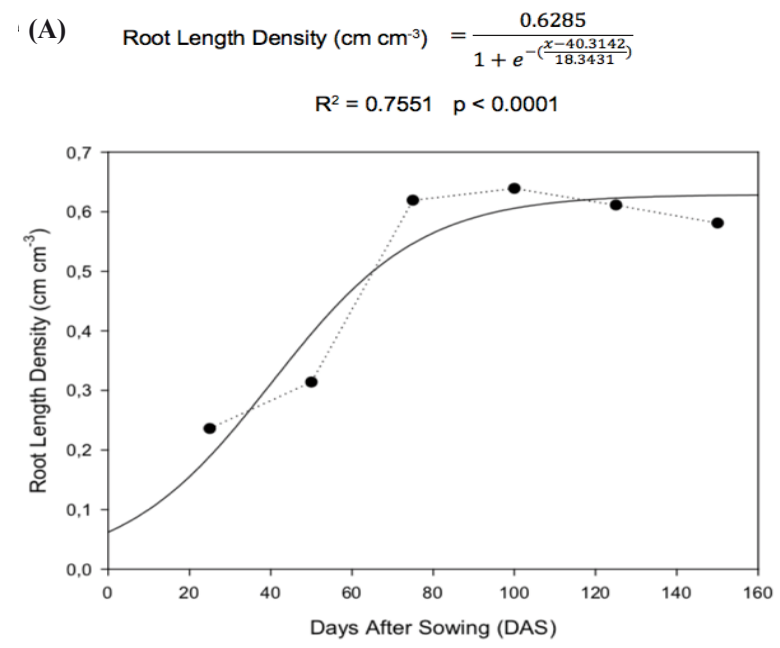

(B) Root Mass Density $\left(\mathrm{mg} \mathrm{cm}^{-3}\right)=\frac{0.5696}{1+e^{-\left(\frac{x-40.5290}{18.2618}\right)}}$

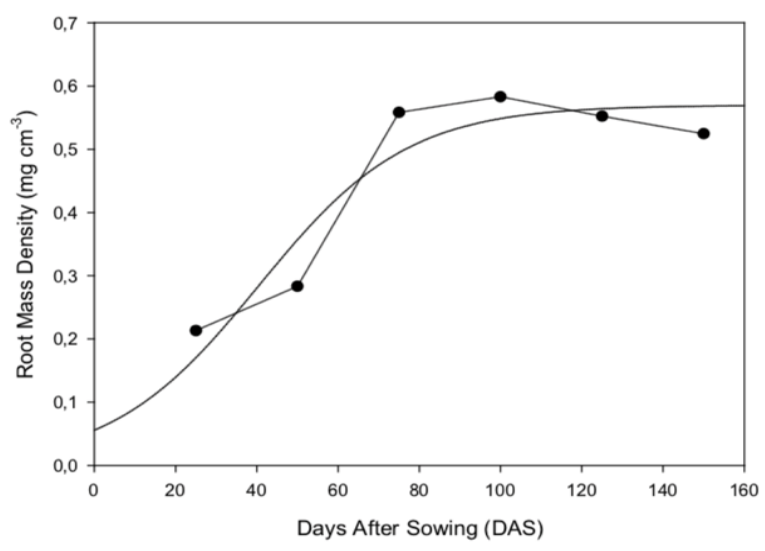

Figure 2. Relationship between plant age (days after sowing) and (A) root length density (RLD) $(0-60 \mathrm{~cm})$ and $(\mathrm{B})$ root mass density (RMD) $(0-60 \mathrm{~cm})$ 
Table 2A. Effects of tillage systems (conventional and minimum tillage: CT and MT, respectively) and fertilization (control, inorganic fertilization $100 \mathrm{~kg} \mathrm{~N} \mathrm{ha}^{-1}(\mathrm{~N} 1)$, inorganic fertilization $200 \mathrm{~kg} \mathrm{~N} \mathrm{ha}^{-1}$ (N2) and manure) on root length density $\left(\mathrm{cm} \mathrm{cm}^{-3}\right)$ of quinoa crops in 2011

\begin{tabular}{|c|c|c|c|c|c|c|c|c|c|c|c|c|}
\hline \multirow[b]{2}{*}{ Fertilization } & \multicolumn{12}{|c|}{ Tillage system } \\
\hline & $\mathrm{CT}$ & MT & $\mathrm{CT}$ & MT & $\mathrm{CT}$ & MT & $\mathrm{CT}$ & MT & $\mathrm{CT}$ & MT & $\mathrm{CT}$ & MT \\
\hline & \multicolumn{12}{|c|}{ Root length density $\left(\mathrm{cm} \mathrm{cm}^{-3}\right)$} \\
\hline & \multicolumn{2}{|c|}{$25 \mathrm{DAS}$} & \multicolumn{2}{|c|}{$50 \mathrm{DAS}$} & \multicolumn{2}{|c|}{75 DAS } & \multicolumn{2}{|c|}{$100 \mathrm{DAS}$} & \multicolumn{2}{|c|}{125 DAS } & \multicolumn{2}{|c|}{150 DAS } \\
\hline \multicolumn{13}{|l|}{$0-30 \mathrm{~cm}$} \\
\hline Control & 0.309 & 0.329 & 0.348 & 0.356 & 0.642 & 0.665 & 0.749 & 0.799 & 0.702 & 0.766 & 0.674 & 0.716 \\
\hline N1 & 0.328 & 0.338 & 0.414 & 0.416 & 0.748 & 0.805 & 0.796 & 0.820 & 0.805 & 0.862 & 0.761 & 0.815 \\
\hline N2 & 0.349 & 0.361 & 0.422 & 0.432 & 0.770 & 0.862 & 0.848 & 0.877 & 0.820 & 0.902 & 0.770 & 0.875 \\
\hline Manure & 0.336 & 0.347 & 0.420 & 0.411 & 0.771 & 0.847 & 0.815 & 0.845 & 0.801 & 0.894 & 0.768 & 0.834 \\
\hline $\mathrm{F}_{\text {tillage }}$ & \multicolumn{2}{|c|}{$1.29^{\mathrm{ns}}$} & \multicolumn{2}{|c|}{$0.04^{\mathrm{ns}}$} & \multicolumn{2}{|c|}{$\begin{array}{c}6.27 * \\
(\text { Tukey }=0.086)\end{array}$} & \multicolumn{2}{|c|}{$1.34^{\mathrm{ns}}$} & \multicolumn{2}{|c|}{$\begin{array}{c}57.02 * * * \\
(\text { Tukey }=0.075)\end{array}$} & \multicolumn{2}{|c|}{$\begin{array}{c}17.19 * * \\
(\text { Tukey }=0.078)\end{array}$} \\
\hline $\mathrm{F}_{\text {fertilization }}$ & \multicolumn{2}{|c|}{$1.60^{\mathrm{ns}}$} & \multicolumn{2}{|c|}{$\begin{array}{c}6.70 * \\
(\text { Tukey }=0.046)\end{array}$} & \multicolumn{2}{|c|}{$\begin{array}{c}9.43 * * \\
(\text { Tukey }=0.117)\end{array}$} & \multicolumn{2}{|c|}{$1.65^{\mathrm{ns}}$} & \multicolumn{2}{|c|}{$\begin{array}{c}34.82 * * * \\
(\text { Tukey }=0.121)\end{array}$} & \multicolumn{2}{|c|}{$\begin{array}{c}12.15^{* *} \\
(\text { Tukey }=0.094)\end{array}$} \\
\hline $\mathrm{F}_{\text {tillage }} \times$ fertilization & \multicolumn{2}{|c|}{$0.04^{\mathrm{ns}}$} & \multicolumn{2}{|c|}{$0.10^{\mathrm{ns}}$} & \multicolumn{2}{|c|}{$0.35^{\mathrm{ns}}$} & \multicolumn{2}{|c|}{$0.04^{\mathrm{ns}}$} & \multicolumn{2}{|c|}{$0.69^{\mathrm{ns}}$} & \multicolumn{2}{|c|}{$0.02^{\mathrm{ns}}$} \\
\hline \multicolumn{13}{|l|}{$30-60 \mathrm{~cm}$} \\
\hline Control & 0.094 & 0.099 & 0.154 & 0.158 & 0.311 & 0.333 & 0.336 & 0.363 & 0.323 & 0.326 & 0.304 & 0.327 \\
\hline N1 & 0.105 & 0.111 & 0.167 & 0.182 & 0.353 & 0.375 & 0.357 & 0.368 & 0.362 & 0.380 & 0.342 & 0.365 \\
\hline $\mathrm{N} 2$ & 0.107 & 0.122 & 0.168 & 0.191 & 0.356 & 0.389 & 0.396 & 0.393 & 0.361 & 0.401 & 0.345 & 0.369 \\
\hline Manure & 0.098 & 0.118 & 0.155 & 0.189 & 0.317 & 0.390 & 0.366 & 0.379 & 0.435 & 0.402 & 0.305 & 0.388 \\
\hline $\mathrm{F}_{\text {tillage }}$ & \multicolumn{2}{|c|}{$\begin{array}{c}28.44 * * * \\
(\text { Tukey }=0.009)\end{array}$} & \multicolumn{2}{|c|}{$\begin{array}{c}32.28 * * * \\
(\text { Tukey }=0.013)\end{array}$} & \multicolumn{2}{|c|}{$\begin{array}{c}34.44 * * * \\
(\text { Tukey }=0.027)\end{array}$} & \multicolumn{2}{|c|}{$0.59^{\text {ns }}$} & $\begin{array}{r}23.7 \\
\text { (Tukey }\end{array}$ & $\begin{array}{l}* * \\
0.036)\end{array}$ & $\begin{array}{r}24 . \\
\text { (Tukey }\end{array}$ & $\begin{array}{l}4 * * \\
0.027)\end{array}$ \\
\hline $\mathrm{F}_{\text {fertilization }}$ & $\begin{array}{r}11.0 \\
\text { (Tukey }\end{array}$ & $\begin{array}{l}* * * * \\
=0.013)\end{array}$ & $\begin{array}{r}8.93 \\
\text { (Tukey }\end{array}$ & $\begin{array}{l}* * * \\
=0.021)\end{array}$ & $\begin{array}{r}12 . \\
\text { (Tukey }\end{array}$ & $\begin{array}{l}6 * * \\
0.041)\end{array}$ & & & $\begin{array}{r}5.8 \\
\text { (Tukey }\end{array}$ & $\begin{array}{l}7 * \\
0.061)\end{array}$ & $\begin{array}{r}5 . \\
\text { (Tukey }\end{array}$ & $0.039)$ \\
\hline $\mathrm{F}_{\text {tillage } \times \text { fertilization }}$ & 2.5 & & 3.3 & & & & & & & & & \\
\hline
\end{tabular}

Explanations: see Table 1

Table 2B. Effects of tillage systems (conventional and minimum tillage: CT and MT, respectively) and fertilization (control, inorganic fertilization $100 \mathrm{~kg} \mathrm{~N} \mathrm{ha}^{-1}$ (N1), inorganic fertilization $200 \mathrm{~kg} \mathrm{~N} \mathrm{ha}^{-1}$ (N2) and manure) on root length density $\left(\mathrm{cm} \mathrm{cm}^{-3}\right)$ of quinoa crops in 2012

\begin{tabular}{|c|c|c|c|c|c|c|c|c|c|c|c|c|}
\hline \multirow[b]{2}{*}{ Fertilization } & \multicolumn{12}{|c|}{ Tillage system } \\
\hline & $\mathrm{CT}$ & MT & $\mathrm{CT}$ & MT & $\mathrm{CT}$ & MT & $\mathrm{CT}$ & MT & $\mathrm{CT}$ & MT & $\mathrm{CT}$ & MT \\
\hline & \multicolumn{12}{|c|}{ Root length density $\left(\mathrm{cm} \mathrm{cm}^{-3}\right)$} \\
\hline & \multicolumn{2}{|c|}{$25 \mathrm{DAS}$} & \multicolumn{2}{|c|}{$50 \mathrm{DAS}$} & \multicolumn{2}{|c|}{75 DAS } & \multicolumn{2}{|c|}{$100 \mathrm{DAS}$} & \multicolumn{2}{|c|}{$125 \mathrm{DAS}$} & \multicolumn{2}{|c|}{$150 \mathrm{DAS}$} \\
\hline \multicolumn{13}{|l|}{$0-30 \mathrm{~cm}$} \\
\hline Control & 0.314 & 0.285 & 0.342 & 0.396 & 0.775 & 0.794 & 0.670 & 0.778 & 0.728 & 0.671 & 0.698 & 0.645 \\
\hline N1 & 0.386 & 0.390 & 0.437 & 0.517 & 0.890 & 0.947 & 0.782 & 1.103 & 0.792 & 0.786 & 0.753 & 0.748 \\
\hline N2 & 0.399 & 0.387 & 0.438 & 0.475 & 0.908 & 0.977 & 0.971 & 0.972 & 0.801 & 0.805 & 0.769 & 0.765 \\
\hline Manure & 0.394 & 0.364 & 0.461 & 0.480 & 0.882 & 0.940 & 0.926 & 0.959 & 0.797 & 0.795 & 0.753 & 0.751 \\
\hline $\mathrm{F}_{\text {tillage }}$ & \multicolumn{2}{|c|}{$0.70^{\mathrm{ns}}$} & \multicolumn{2}{|c|}{$\begin{array}{c}15.04 * * \\
(\text { Tukey }=0.055)\end{array}$} & \multicolumn{2}{|c|}{$\begin{array}{c}5.45^{*} \\
(\text { Tukey }=0.079)\end{array}$} & \multicolumn{2}{|c|}{$\begin{array}{c}10.51^{*} \\
(\text { Tukey }=0.116)\end{array}$} & \multicolumn{2}{|c|}{$1.28^{\mathrm{ns}}$} & \multicolumn{2}{|c|}{$1.91^{\mathrm{ns}}$} \\
\hline $\mathrm{F}_{\text {fertilization }}$ & \multicolumn{2}{|c|}{$\begin{array}{c}4.98^{*} \\
(\text { Tukey }=0.072)\end{array}$} & \multicolumn{2}{|c|}{$\begin{array}{c}16.69 * * * \\
(\text { Tukey }=0.076)\end{array}$} & \multicolumn{2}{|c|}{$\begin{array}{c}10.79 * * \\
(\text { Tukey }=0.098)\end{array}$} & \multicolumn{2}{|c|}{$\begin{array}{c}10.32 * * \\
(\text { Tukey }=0.176)\end{array}$} & \multirow{2}{*}{\multicolumn{2}{|c|}{$\begin{array}{c}12.79 * * \\
(\text { Tukey }=0.083) \\
041^{\text {ns }}\end{array}$}} & \multicolumn{2}{|c|}{$\begin{array}{c}13.36^{* *} \\
(\text { Tukey }=0.056)\end{array}$} \\
\hline $\mathrm{F}_{\text {tillage }} \times$ fertilization & \multicolumn{2}{|c|}{$0.17^{\mathrm{ns}}$} & \multicolumn{2}{|c|}{$1.11^{\mathrm{ns}}$} & \multicolumn{2}{|c|}{$0.25^{\mathrm{ns}}$} & \multicolumn{2}{|c|}{$4.07 \mathrm{~ns}$} & & & \multicolumn{2}{|c|}{$1.16^{\mathrm{ns}}$} \\
\hline \multicolumn{13}{|l|}{$30-60 \mathrm{~cm}$} \\
\hline Control & 0.104 & 0.102 & 0.168 & 0.160 & 0.362 & 0.337 & 0.342 & 0.311 & 0.374 & 0.346 & 0.354 & 0.327 \\
\hline N1 & 0.120 & 0.116 & 0.189 & 0.184 & 0.386 & 0.379 & 0.420 & 0.425 & 0.395 & 0.392 & 0.379 & 0.376 \\
\hline N2 & 0.119 & 0.115 & 0.190 & 0.187 & 0.396 & 0.393 & 0.434 & 0.422 & 0.416 & 0.406 & 0.402 & 0.386 \\
\hline Manure & 0.113 & 0.111 & 0.179 & 0.176 & 0.380 & 0.389 & 0.429 & 0.397 & 0.392 & 0.388 & 0.374 & 0.369 \\
\hline $\mathrm{F}_{\text {tillage }}$ & \multicolumn{2}{|c|}{$0.72^{\text {ns }}$} & \multicolumn{2}{|c|}{$1.05^{\mathrm{ns}}$} & \multicolumn{2}{|c|}{$0.29^{\mathrm{ns}}$} & \multicolumn{2}{|c|}{$0.67^{\mathrm{ns}}$} & \multicolumn{2}{|c|}{$1.77^{\mathrm{ns}}$} & & \\
\hline $\mathrm{F}_{\text {fertilization }}$ & $\begin{array}{r}4 . \\
\text { (Tukey }\end{array}$ & $\begin{array}{l}0 * \\
=0.012)\end{array}$ & $\begin{array}{r}5.7 \\
\text { (Tukey }\end{array}$ & $0.017)$ & & & $\begin{array}{r}4.9 \\
\text { (Tukey }\end{array}$ & $\begin{array}{l}6^{*} \\
=0.058)\end{array}$ & $\begin{array}{r}5.6 \\
\text { (Tukey }\end{array}$ & $0.048)$ & $\begin{array}{r}5 . \\
\text { (Tukey }\end{array}$ & $\begin{array}{l}3^{*} \\
0.037)\end{array}$ \\
\hline $\mathrm{F}_{\text {tillage } \times \text { fertilization }}$ & & & 0.0 & & & & 0.1 & & 0.4 & & & \\
\hline
\end{tabular}

Explanations: see Table 1 
Table 2C. Effects of tillage systems (conventional and minimum tillage: CT and MT, respectively) and fertilization (control, inorganic fertilization $100 \mathrm{~kg} \mathrm{~N} \mathrm{ha}^{-1}(\mathrm{~N} 1)$, inorganic fertilization $200 \mathrm{~kg} \mathrm{~N} \mathrm{ha}^{-1}$ (N2) and manure) on root length density $\left(\mathrm{cm} \mathrm{cm}^{-3}\right)$ of quinoa crops in 2013

\begin{tabular}{|c|c|c|c|c|c|c|c|c|c|c|c|c|}
\hline \multirow[b]{2}{*}{ Fertilization } & \multicolumn{12}{|c|}{ Tillage system } \\
\hline & $\mathrm{CT}$ & MT & $\mathrm{CT}$ & MT & $\mathrm{CT}$ & MT & $\mathrm{CT}$ & MT & $\mathrm{CT}$ & MT & $\mathrm{CT}$ & MT \\
\hline & \multicolumn{12}{|c|}{ Root length density $\left(\mathrm{cm} \mathrm{cm}^{-3}\right)$} \\
\hline & \multicolumn{2}{|c|}{$25 \mathrm{DAS}$} & \multicolumn{2}{|c|}{50 DAS } & \multicolumn{2}{|c|}{75 DAS } & \multicolumn{2}{|c|}{100 DAS } & \multicolumn{2}{|c|}{$125 \mathrm{DAS}$} & \multicolumn{2}{|c|}{150 DAS } \\
\hline \multicolumn{13}{|l|}{$0-30 \mathrm{~cm}$} \\
\hline Control & 0.330 & 0.308 & 0.377 & 0.405 & 0.783 & 0.773 & 0.675 & 0.855 & 0.842 & 0.841 & 0.746 & 0.746 \\
\hline N1 & 0.359 & 0.433 & 0.429 & 0.526 & 0.885 & 1.019 & 0.978 & 0.945 & 0.986 & 1.010 & 0.878 & 0.894 \\
\hline N2 & 0.483 & 0.481 & 0.612 & 0.608 & 1.097 & 1.205 & 1.114 & 1.229 & 1.075 & 1.066 & 0.977 & 0.968 \\
\hline Manure & 0.312 & 0.345 & 0.450 & 0.563 & 0.787 & 0.823 & 0.859 & 0.737 & 0.898 & 0.937 & 0.804 & 0.835 \\
\hline $\mathrm{F}_{\text {tillage }}$ & \multicolumn{2}{|c|}{$1.54^{\mathrm{ns}}$} & \multicolumn{2}{|c|}{$\begin{array}{c}13.61^{* *} \\
(\text { Tukey }=0.097)\end{array}$} & \multicolumn{2}{|c|}{$2.63^{\mathrm{ns}}$} & \multicolumn{2}{|c|}{$0.28^{\mathrm{ns}}$} & \multicolumn{2}{|c|}{$0.13^{\mathrm{ns}}$} & \multicolumn{2}{|c|}{$0.07^{\mathrm{ns}}$} \\
\hline $\mathrm{F}_{\text {fertilization }}$ & \multicolumn{2}{|c|}{$\begin{array}{c}20.04 * * * \\
(\text { Tukey }=0.077)\end{array}$} & \multicolumn{2}{|c|}{$\begin{array}{c}32.72 * * * \\
(\text { Tukey }=0.107)\end{array}$} & \multicolumn{2}{|c|}{$\begin{array}{c}17.04 * * * \\
(\text { Tukey }=0.178)\end{array}$} & \multicolumn{2}{|c|}{$\begin{array}{c}7.92 * * \\
(\text { Tukey }=0.199)\end{array}$} & \multicolumn{2}{|c|}{$\begin{array}{c}7.58 * * \\
(\text { Tukey }=0.158)\end{array}$} & \multicolumn{2}{|c|}{$\begin{array}{c}7.35^{*} \\
(\text { Tukey }=0.121)\end{array}$} \\
\hline $\mathrm{F}_{\text {tillage } \times \text { fertilization }}$ & \multicolumn{2}{|c|}{$1.59^{\mathrm{ns}}$} & \multicolumn{2}{|c|}{$3.07^{\mathrm{ns}}$} & \multicolumn{2}{|c|}{$0.63^{\text {ns }}$} & \multicolumn{2}{|c|}{$1.09^{\text {ns }}$} & \multicolumn{2}{|c|}{$0.08^{\mathrm{ns}}$} & \multicolumn{2}{|c|}{$0.06^{\mathrm{ns}}$} \\
\hline \multicolumn{13}{|l|}{$30-60 \mathrm{~cm}$} \\
\hline Control & 0.108 & 0.104 & 0.178 & 0.171 & 0.370 & 0.367 & 0.360 & 0.335 & 0.387 & 0.379 & 0.366 & 0.358 \\
\hline N1 & 0.122 & 0.121 & 0.201 & 0.196 & 0.418 & 0.422 & 0.391 & 0.472 & 0.439 & 0.431 & 0.415 & 0.418 \\
\hline N2 & 0.128 & 0.116 & 0.223 & 0.195 & 0.465 & 0.448 & 0.526 & 0.514 & 0.474 & 0.465 & 0.446 & 0.440 \\
\hline Manure & 0.115 & 0.121 & 0.183 & 0.193 & 0.387 & 0.398 & 0.340 & 0.376 & 0.401 & 0.424 & 0.374 & 0.413 \\
\hline$\overline{\mathrm{F}_{\text {tillage }}}$ & \multicolumn{2}{|c|}{$0.33^{\text {ns }}$} & \multicolumn{2}{|c|}{$0.66^{\text {ns }}$} & \multicolumn{2}{|c|}{$0.01^{\mathrm{ns}}$} & \multicolumn{2}{|c|}{$1.18^{\mathrm{ns}}$} & 0. & & & \\
\hline $\mathrm{F}_{\text {fertilization }}$ & & & & & $\begin{array}{r}4 . \\
\text { (Tukey }\end{array}$ & $\begin{array}{l}4^{*} \\
=0.064)\end{array}$ & $\begin{array}{r}18.5 \\
\text { (Tukey }\end{array}$ & $\begin{array}{l}* * * \\
0.062)\end{array}$ & $\begin{array}{r}4 .{ }^{4} \\
\text { (Tukey }\end{array}$ & $\begin{array}{l}4^{*} \\
=0.082)\end{array}$ & $\begin{array}{r}4 . \\
\text { (Tukey }\end{array}$ & $\begin{array}{l}1 * \\
0.061)\end{array}$ \\
\hline $\mathrm{F}_{\text {tillage }} \times$ fertilization & & & 0.7 & & & & & & 0.2 & & & \\
\hline
\end{tabular}

Explanations: see Table 1

Table 3A. Effects of tillage systems (conventional and minimum tillage: CT and MT, respectively) and fertilization (control, inorganic fertilization $100 \mathrm{~kg} \mathrm{~N} \mathrm{ha}^{-1}(\mathrm{~N} 1)$, inorganic fertilization $200 \mathrm{~kg} \mathrm{~N} \mathrm{ha}^{-1}$ (N2) and manure) on root mass density $\left(\mathrm{mg} \mathrm{cm}^{-3}\right)$ of quinoa crops in 2011

\begin{tabular}{|c|c|c|c|c|c|c|c|c|c|c|c|c|}
\hline \multirow[b]{2}{*}{ Fertilization } & \multicolumn{12}{|c|}{ Tillage system } \\
\hline & $\mathrm{CT}$ & MT & $\mathrm{CT}$ & MT & $\mathrm{CT}$ & MT & $\mathrm{CT}$ & MT & $\mathrm{CT}$ & MT & $\mathrm{CT}$ & MT \\
\hline & \multicolumn{12}{|c|}{ Root mass density $\left(\mathrm{mg} \mathrm{cm}^{-3}\right)$} \\
\hline & \multicolumn{2}{|c|}{$25 \mathrm{DAS}$} & \multicolumn{2}{|c|}{$50 \mathrm{DAS}$} & \multicolumn{2}{|c|}{75 DAS } & \multicolumn{2}{|c|}{100 DAS } & \multicolumn{2}{|c|}{$125 \mathrm{DAS}$} & \multicolumn{2}{|c|}{150 DAS } \\
\hline \multicolumn{13}{|l|}{$0-30 \mathrm{~cm}$} \\
\hline Control & 0.279 & 0.291 & 0.316 & 0.313 & 0.570 & 0.586 & 0.689 & 0.720 & 0.622 & 0.670 & 0.594 & 0.635 \\
\hline N1 & 0.294 & 0.306 & 0.378 & 0.382 & 0.634 & 0.737 & 0.725 & 0.755 & 0.729 & 0.788 & 0.694 & 0.751 \\
\hline $\mathrm{N} 2$ & 0.312 & 0.325 & 0.379 & 0.391 & 0.688 & 0.753 & 0.770 & 0.802 & 0.734 & 0.787 & 0.698 & 0.736 \\
\hline Manure & 0.306 & 0.327 & 0.383 & 0.370 & 0.726 & 0.784 & 0.755 & 0.807 & 0.749 & 0.823 & 0.722 & 0.772 \\
\hline $\mathrm{F}_{\text {tillage }}$ & \multicolumn{2}{|c|}{$1.31^{\mathrm{ns}}$} & \multicolumn{2}{|c|}{$0.11^{\mathrm{ns}}$} & \multicolumn{2}{|c|}{$\begin{array}{c}6.37 * \\
(\text { Tukey }=0.087)\end{array}$} & \multicolumn{2}{|c|}{$1.31^{\mathrm{ns}}$} & \multicolumn{2}{|c|}{$\begin{array}{c}28.54 * * * \\
(\text { Tukey }=0.081)\end{array}$} & \multicolumn{2}{|c|}{$\begin{array}{c}20.42 * * \\
(\text { Tukey }=0.059)\end{array}$} \\
\hline $\mathrm{F}_{\text {fertilization }}$ & \multicolumn{2}{|c|}{$1.49^{\mathrm{ns}}$} & \multicolumn{2}{|c|}{$\begin{array}{c}5.54 * \\
(\text { Tukey }=0.049)\end{array}$} & \multicolumn{2}{|c|}{$\begin{array}{c}10.18^{* *} \\
(\text { Tukey }=0.116)\end{array}$} & \multicolumn{2}{|c|}{$1.49^{\mathrm{ns}}$} & \multicolumn{2}{|c|}{$\begin{array}{c}31.34 * * * \\
(\text { Tukey }=0.103)\end{array}$} & \multicolumn{2}{|c|}{$\begin{array}{c}32.03 * * * \\
(\text { Tukey }=0.085)\end{array}$} \\
\hline $\mathrm{F}_{\text {tillage } \times \text { fertilization }}$ & \multicolumn{2}{|c|}{$0.03^{\mathrm{ns}}$} & \multicolumn{2}{|c|}{$0.15^{\text {ns }}$} & \multicolumn{2}{|c|}{$0.54^{\text {ns }}$} & \multicolumn{2}{|c|}{$0.03^{\mathrm{ns}}$} & & & \multicolumn{2}{|c|}{$0.18^{\mathrm{ns}}$} \\
\hline \multicolumn{13}{|l|}{$30-60 \mathrm{~cm}$} \\
\hline Control & 0.082 & 0.087 & 0.124 & 0.150 & 0.291 & 0.299 & 0.309 & 0.323 & 0.312 & 0.325 & 0.297 & 0.306 \\
\hline N1 & 0.096 & 0.103 & 0.138 & 0.179 & 0.319 & 0.337 & 0.326 & 0.339 & 0.354 & 0.373 & 0.334 & 0.366 \\
\hline N2 & 0.095 & 0.109 & 0.137 & 0.181 & 0.318 & 0.345 & 0.346 & 0.362 & 0.326 & 0.388 & 0.410 & 0.362 \\
\hline Manure & 0.088 & 0.107 & 0.135 & 0.185 & 0.283 & 0.350 & 0.341 & 0.363 & 0.315 & 0.386 & 0.328 & 0.375 \\
\hline $\mathrm{F}_{\text {tillage }}$ & \multirow{2}{*}{\multicolumn{2}{|c|}{$\begin{array}{c}17.61^{* *} \\
(\text { Tukey }=0.009) \\
8.26 * * \\
(\text { Tukey }=0.013)\end{array}$}} & \multicolumn{2}{|c|}{$\begin{array}{c}27.68 * * * \\
(\text { Tukey }=0.017)\end{array}$} & \multicolumn{2}{|c|}{$1.78^{\mathrm{ns}}$} & \multicolumn{2}{|c|}{$1.40^{\mathrm{ns}}$} & \multicolumn{2}{|c|}{$3.00^{\mathrm{ns}}$} & & \\
\hline $\mathrm{F}_{\text {fertilization }}$ & & & & & & & & & & & & \\
\hline $\mathrm{F}_{\text {tillage } \times \text { fertilization }}$ & 1. & $5^{\mathrm{ns}}$ & & & & & & & & & & \\
\hline
\end{tabular}

Explanations: see Table 1 
Table 3B. Effects of tillage systems (conventional and minimum tillage: CT and MT, respectively) and fertilization (control, inorganic fertilization $100 \mathrm{~kg} \mathrm{~N} \mathrm{ha}^{-1}(\mathrm{~N} 1)$, inorganic fertilization $200 \mathrm{~kg} \mathrm{~N} \mathrm{ha}^{-1}$ (N2) and manure) on root mass density $\left(\mathrm{mg} \mathrm{cm}^{-3}\right)$ of quinoa crops in 2012

\begin{tabular}{|c|c|c|c|c|c|c|c|c|c|c|c|c|}
\hline \multirow[b]{2}{*}{ Fertilization } & \multicolumn{12}{|c|}{ Tillage system } \\
\hline & $\mathrm{CT}$ & MT & $\mathrm{CT}$ & MT & $\mathrm{CT}$ & MT & $\mathrm{CT}$ & MT & $\mathrm{CT}$ & MT & $\mathrm{CT}$ & MT \\
\hline & \multicolumn{12}{|c|}{ Root mass density $\left(\mathrm{mg} \mathrm{cm}^{-3}\right)$} \\
\hline & \multicolumn{2}{|c|}{$25 \mathrm{DAS}$} & \multicolumn{2}{|c|}{$50 \mathrm{DAS}$} & \multicolumn{2}{|c|}{75 DAS } & \multicolumn{2}{|c|}{100 DAS } & \multicolumn{2}{|c|}{$125 \mathrm{DAS}$} & \multicolumn{2}{|c|}{$150 \mathrm{DAS}$} \\
\hline \multicolumn{13}{|l|}{$0-30 \mathrm{~cm}$} \\
\hline Control & 0.274 & 0.253 & 0.314 & 0.372 & 0.701 & 0.718 & 0.603 & 0.701 & 0.683 & 0.639 & 0.638 & 0.609 \\
\hline N1 & 0.354 & 0.362 & 0.393 & 0.466 & 0.799 & 0.880 & 0.682 & 0.866 & 0.776 & 0.783 & 0.744 & 0.754 \\
\hline N2 & 0.350 & 0.349 & 0.387 & 0.414 & 0.822 & 0.887 & 0.861 & 0.867 & 0.754 & 0.782 & 0.726 & 0.740 \\
\hline Manure & 0.367 & 0.334 & 0.415 & 0.433 & 0.789 & 0.835 & 0.793 & 0.931 & 0.785 & 0.791 & 0.748 & 0.749 \\
\hline $\mathrm{F}_{\text {tillage }}$ & \multicolumn{2}{|c|}{$0.24^{\mathrm{ns}}$} & \multicolumn{2}{|c|}{$\begin{array}{c}12.54 * * \\
(\text { Tukey }=0.046)\end{array}$} & \multicolumn{2}{|c|}{$\begin{array}{c}5.36^{*} \\
(\text { Tukey }=0.076)\end{array}$} & \multicolumn{2}{|c|}{$2.28^{\mathrm{ns}}$} & \multicolumn{2}{|c|}{$0.18^{\mathrm{ns}}$} & \multicolumn{2}{|c|}{$0.09^{\mathrm{ns}}$} \\
\hline $\mathrm{F}_{\text {fertilization }}$ & \multicolumn{2}{|c|}{$\begin{array}{c}3.99 * \\
(\text { Tukey }=0.082)\end{array}$} & \multicolumn{2}{|c|}{$\begin{array}{c}10.05^{* *} \\
(\text { Tukey }=0.074)\end{array}$} & \multicolumn{2}{|c|}{$\begin{array}{c}8.25^{* *} \\
(\text { Tukey }=0.104)\end{array}$} & \multicolumn{2}{|c|}{$2.02^{\mathrm{ns}}$} & \multirow{2}{*}{\multicolumn{2}{|c|}{$\begin{array}{c}9.14 * * \\
(\text { Tukey }=0.099)\end{array}$}} & \multicolumn{2}{|c|}{$\begin{array}{c}12.07 * * \\
(\text { Tukey }=0.062)\end{array}$} \\
\hline $\mathrm{F}_{\text {tillage }} \times$ fertilization & \multicolumn{2}{|c|}{$0.15^{\mathrm{ns}}$} & \multicolumn{2}{|c|}{$0.41 \mathrm{~ns}$} & \multicolumn{2}{|c|}{$0.37^{\mathrm{ns}}$} & \multicolumn{2}{|c|}{$0.29^{\mathrm{ns}}$} & & & \multicolumn{2}{|c|}{$0.31^{\mathrm{ns}}$} \\
\hline \multicolumn{13}{|l|}{$30-60 \mathrm{~cm}$} \\
\hline Control & 0.093 & 0.089 & 0.175 & 0.114 & 0.323 & 0.299 & 0.305 & 0.281 & 0.342 & 0.323 & 0.316 & 0.302 \\
\hline N1 & 0.108 & 0.104 & 0.229 & 0.115 & 0.353 & 0.350 & 0.393 & 0.401 & 0.353 & 0.352 & 0.341 & 0.338 \\
\hline $\mathrm{N} 2$ & 0.106 & 0.101 & 0.191 & 0.144 & 0.347 & 0.349 & 0.389 & 0.388 & 0.368 & 0.356 & 0.351 & 0.346 \\
\hline Manure & 0.104 & 0.102 & 0.173 & 0.156 & 0.355 & 0.357 & 0.404 & 0.371 & 0.354 & 0.349 & 0.330 & 0.328 \\
\hline $\mathrm{F}_{\text {tillage }}$ & \multicolumn{2}{|c|}{$1.50^{\mathrm{ns}}$} & \multicolumn{2}{|c|}{$\begin{array}{c}6.91 * \\
(\text { Tukey }=0.044)\end{array}$} & \multicolumn{2}{|c|}{$0.18^{\mathrm{ns}}$} & \multicolumn{2}{|c|}{$0.24^{\mathrm{ns}}$} & \multicolumn{2}{|c|}{$1.51^{\mathrm{ns}}$} & 0.5 & \\
\hline $\mathrm{F}_{\text {fertilization }}$ & $\begin{array}{r}4 . \\
\text { (Tukey }\end{array}$ & $\begin{array}{l}* \\
0.013)\end{array}$ & & & & & & & 2.5 & & $\begin{array}{r}4.3 \\
\text { (Tukey }\end{array}$ & $0.028)$ \\
\hline $\mathrm{F}_{\text {tillage }} \times$ fertilization & 0. & & & & & & & & & & & \\
\hline
\end{tabular}

Explanations: see Table 1

Table 3C. Effects of tillage systems (conventional and minimum tillage: CT and MT, respectively) and fertilization (control, inorganic fertilization $100 \mathrm{~kg} \mathrm{~N} \mathrm{ha}^{-1}(\mathrm{~N} 1)$, inorganic fertilization $200 \mathrm{~kg} \mathrm{~N} \mathrm{ha}^{-1}$ (N2) and manure) on root mass density $\left(\mathrm{mg} \mathrm{cm}^{-3}\right)$ of quinoa crops in 2013

\begin{tabular}{|c|c|c|c|c|c|c|c|c|c|c|c|c|}
\hline \multirow[b]{2}{*}{ Fertilization } & \multicolumn{12}{|c|}{ Tillage system } \\
\hline & $\mathrm{CT}$ & MT & $\mathrm{CT}$ & MT & $\mathrm{CT}$ & MT & $\mathrm{CT}$ & MT & $\mathrm{CT}$ & MT & $\mathrm{CT}$ & MT \\
\hline & \multicolumn{12}{|c|}{ Root mass density $\left(\mathrm{mg} \mathrm{cm}^{-3}\right)$} \\
\hline & \multicolumn{2}{|c|}{$25 \mathrm{DAS}$} & \multicolumn{2}{|c|}{$50 \mathrm{DAS}$} & \multicolumn{2}{|c|}{75 DAS } & \multicolumn{2}{|c|}{$100 \mathrm{DAS}$} & \multicolumn{2}{|c|}{125 DAS } & \multicolumn{2}{|c|}{$150 \mathrm{DAS}$} \\
\hline \multicolumn{13}{|l|}{$0-30 \mathrm{~cm}$} \\
\hline Control & 0.300 & 0.286 & 0.357 & 0.370 & 0.722 & 0.713 & 0.681 & 0.802 & 0.701 & 0.708 & 0.665 & 0.677 \\
\hline N1 & 0.321 & 0.383 & 0.386 & 0.461 & 0.790 & 0.935 & 0.896 & 0.979 & 0.855 & 0.871 & 0.806 & 0.819 \\
\hline $\mathrm{N} 2$ & 0.437 & 0.424 & 0.536 & 0.547 & 0.986 & 1.083 & 1.033 & 1.114 & 1.213 & 0.938 & 0.886 & 0.889 \\
\hline Manure & 0.279 & 0.311 & 0.405 & 0.511 & 0.696 & 0.741 & 0.689 & 0.778 & 0.909 & 0.764 & 0.709 & 0.708 \\
\hline $\mathrm{F}_{\text {tillage }}$ & \multicolumn{2}{|c|}{$1.09^{\mathrm{ns}}$} & \multicolumn{2}{|c|}{$\begin{array}{c}10.47^{*} \\
(\text { Tukey }=0.082)\end{array}$} & \multicolumn{2}{|c|}{$3.38^{\mathrm{ns}}$} & \multicolumn{2}{|c|}{$3.21^{\mathrm{ns}}$} & \multicolumn{2}{|c|}{$0.34^{\mathrm{ns}}$} & \multicolumn{2}{|c|}{$0.05^{\mathrm{ns}}$} \\
\hline $\mathrm{F}_{\text {fertilization }}$ & \multicolumn{2}{|c|}{$\begin{array}{c}16.58^{* * *} \\
(\text { Tukey }=0.069)\end{array}$} & \multicolumn{2}{|c|}{$\begin{array}{c}21.82 * * * \\
(\text { Tukey }=0.096)\end{array}$} & \multirow{2}{*}{\multicolumn{2}{|c|}{$\begin{array}{c}15.90^{* *} \\
(\text { Tukey }=0.169) \\
0.77^{\text {ns }}\end{array}$}} & \multirow{2}{*}{\multicolumn{2}{|c|}{$\begin{array}{c}9.88^{* *} \\
(\text { Tukey }=0.156) \\
0.03^{\text {ns }} \\
\end{array}$}} & \multirow{2}{*}{\multicolumn{2}{|c|}{$\begin{array}{c}11.99 * * \\
(\text { Tukey }=0.135) \\
0.02^{\mathrm{ns}}\end{array}$}} & \multicolumn{2}{|c|}{$\begin{array}{c}10.13^{* *} \\
(\text { Tukey }=0.105)\end{array}$} \\
\hline $\mathrm{F}_{\text {tillage } \times \text { fertilization }}$ & \multicolumn{2}{|c|}{$1.37^{\mathrm{ns}}$} & \multicolumn{2}{|c|}{$2.20^{\mathrm{ns}}$} & & & & & & & \multicolumn{2}{|c|}{$0.01^{\mathrm{ns}}$} \\
\hline \multicolumn{13}{|l|}{$30-60 \mathrm{~cm}$} \\
\hline Control & 0.097 & 0.093 & 0.157 & 0.154 & 0.339 & 0.329 & 0.336 & 0.320 & 0.367 & 0.347 & 0.352 & 0.327 \\
\hline N1 & 0.111 & 0.107 & 0.186 & 0.180 & 0.386 & 0.391 & 0.356 & 0.425 & 0.396 & 0.380 & 0.379 & 0.367 \\
\hline $\mathrm{N} 2$ & 0.117 & 0.106 & 0.201 & 0.183 & 0.415 & 0.402 & 0.485 & 0.470 & 0.413 & 0.417 & 0.389 & 0.400 \\
\hline Manure & 0.103 & 0.108 & 0.160 & 0.168 & 0.338 & 0.354 & 0.310 & 0.344 & 0.358 & 0.388 & 0.343 & 0.359 \\
\hline $\mathrm{F}_{\text {tillage }}$ & \multicolumn{2}{|c|}{$0.52^{\text {ns }}$} & \multicolumn{2}{|c|}{$0.27^{\mathrm{ns}}$} & \multicolumn{2}{|c|}{$0.03^{\text {ns }}$} & \multicolumn{2}{|c|}{$1.13^{\mathrm{ns}}$} & \multicolumn{2}{|c|}{$0.03^{\text {ns }}$} & \multicolumn{2}{|c|}{$0.02^{\mathrm{ns}}$} \\
\hline $\mathrm{F}_{\text {fertilization }}$ & & & & & $\begin{array}{r}5 . \\
\text { (Tukey }\end{array}$ & $0.055)$ & $\begin{array}{r}17.0 \\
\text { (Tukey }\end{array}$ & $\begin{array}{l}5 * * * \\
=0.056)\end{array}$ & & & & \\
\hline $\mathrm{F}_{\text {tillage } \times \text { fertilization }}$ & & & & & 0.1 & & & $5^{\mathrm{ns}}$ & & & & \\
\hline
\end{tabular}

Explanations: see Table 1 
associated with low translocation of photosynthetic products due to low leaf area (Fageria and dos Santos, 2013). Root mass density (RMD) was found not to be statistically significant at 100 DAS. Despite the absence of significant effects of tillage on this trait, the plots subjected to minimum tillage presented higher values $\left(0.771\right.$ to $\left.0.981 \mathrm{mg} \mathrm{cm}^{-3}\right)$ compared to the conventional plots $(0.735$ to 0.824 $\mathrm{mg} \mathrm{cm}{ }^{-3}$ ) in the $0-30 \mathrm{~cm}$ soil layer (Tabs $3 \mathrm{~A}, 3 \mathrm{~B}$, 3C). Busari and Salako (2015) had reported that the consistently higher root mass found under minimum tillage probably occurred because this tillage system prevented intense soil perturbation that happened under conventional tillage, resulting in minimized root growth later. Root mass density did not differ among the fertilization regimes in 2011 and 2012, but significant differences were observed during the third year (2013), where the highest value of root mass density in the $0-30 \mathrm{~cm}$ soil layer was found in the plants fertilized with the highest rate of inorganic fertilizer $\left(200 \mathrm{~kg} \mathrm{~N} \mathrm{ha}^{-1}\right)$ (Tabs 3A, 3B, 3C). Gregory (1994) had reported that root mass density and root length density were significantly increased with the addition of nitrogen fertilizer to the soil. In addition, Drew (1975) had found that root weight of barley increased in the zone where the nutrients accumulated, and it was decreased in the nutrient-deficient zone.

\section{Plant height}

Plant height was not influenced by soil tillage, but it was only affected by the different fertilization regimes. During the present experiment, plant height increased linearly with increasing rate of nitrogen fertilizer. In particular, the highest plant height was achieved in the N2 treatment (164-173 $\mathrm{cm})$ followed by N1 $(160-165 \mathrm{~cm})$ and the treatment with manure (154-161 cm) (Tab. 4). The increased height of quinoa plants with the increased nitrogen level was mainly due to the role of nitrogen in

Table 4. Effects of tillage systems (conventional and minimum tillage: CT and MT, respectively) and fertilization (control, inorganic fertilization $100 \mathrm{~kg} \mathrm{~N} \mathrm{ha}^{-1}(\mathrm{~N} 1)$, inorganic fertilization $200 \mathrm{~kg} \mathrm{~N}^{-1}$ (N2) and sheep manure) on plant height $(\mathrm{cm})$, leaf area index, plant dry weight and seed yield $\left(\mathrm{kg} \mathrm{ha}^{-1}\right)$ of quinoa crops

\begin{tabular}{|c|c|c|c|c|c|c|c|c|}
\hline \multirow[b]{2}{*}{ Fertilization } & \multicolumn{8}{|c|}{ Tillage system } \\
\hline & $\mathrm{CT}$ & MT & $\mathrm{CT}$ & MT & $\mathrm{CT}$ & MT & $\mathrm{CT}$ & MT \\
\hline 2011 & \multicolumn{2}{|c|}{ Height $(\mathrm{cm})$} & \multicolumn{2}{|c|}{ LAI } & \multicolumn{2}{|c|}{ Dry weight $\left(\mathrm{kg} \mathrm{ha}^{-1}\right)$} & \multicolumn{2}{|c|}{ Seed yield $\left(\mathrm{kg} \mathrm{ha}^{-1}\right)$} \\
\hline Control & 135 & 136 & 4.40 & 4.30 & 8685 & 8305 & 2415 & 2215 \\
\hline N1 & 164 & 160 & 4.60 & 4.55 & 8880 & 8415 & 2510 & 2315 \\
\hline $\mathrm{N} 2$ & 169 & 164 & 4.85 & 4.55 & 9210 & 8730 & 2525 & 2305 \\
\hline Manure & 155 & 157 & 4.80 & 4.40 & 9100 & 8500 & 2660 & 2390 \\
\hline $\mathrm{F}_{\text {tillage }}$ & \multicolumn{2}{|c|}{$0.52^{\mathrm{ns}}$} & \multicolumn{2}{|c|}{$1.17^{\mathrm{ns}}$} & \multicolumn{2}{|c|}{$3.01^{\mathrm{ns}}$} & \multicolumn{2}{|c|}{$\begin{array}{c}6.25^{*} \\
(\text { Tukey }=167.7)\end{array}$} \\
\hline $\mathrm{F}_{\text {fertilization }}$ & \multicolumn{2}{|c|}{$\begin{array}{c}21.09 * * * \\
(\text { Tukey }=10.8)\end{array}$} & \multicolumn{2}{|c|}{$0.57^{\mathrm{ns}}$} & \multicolumn{2}{|c|}{$0.54^{\mathrm{ns}}$} & \multicolumn{2}{|c|}{$3.03^{\mathrm{ns}}$} \\
\hline $\mathrm{F}_{\text {tillage } \times \text { fertilization }}$ & \multicolumn{2}{|c|}{$0.22^{\mathrm{ns}}$} & \multicolumn{2}{|c|}{$0.18^{\mathrm{ns}}$} & \multicolumn{2}{|c|}{$0.03^{\mathrm{ns}}$} & \multicolumn{2}{|c|}{$0.36^{\mathrm{ns}}$} \\
\hline 2012 & \multicolumn{2}{|c|}{ Height $(\mathrm{cm})$} & \multicolumn{2}{|c|}{ LAI } & \multicolumn{2}{|c|}{ Dry weight $\left(\mathrm{kg} \mathrm{ha}^{-1}\right)$} & \multicolumn{2}{|c|}{ Seed yield $\left(\mathrm{kg} \mathrm{ha}^{-1}\right)$} \\
\hline Control & 144 & 141 & 4.30 & 4.45 & 8205 & 8020 & 2355 & 2080 \\
\hline N1 & 165 & 162 & 4.25 & 4.45 & 8725 & 8390 & 2465 & 2306 \\
\hline $\mathrm{N} 2$ & 171 & 163 & 4.70 & 4.65 & 9165 & 8705 & 2595 & 2295 \\
\hline Manure & 157 & 156 & 4.75 & 4.35 & 9170 & 9010 & 2625 & 2495 \\
\hline$\overline{\mathrm{F}_{\text {tillage }}}$ & \multicolumn{2}{|c|}{$0.92^{\mathrm{ns}}$} & \multicolumn{2}{|c|}{$0.04^{\mathrm{ns}}$} & \multicolumn{2}{|c|}{$0.64^{\mathrm{ns}}$} & \multicolumn{2}{|c|}{$4.56^{\text {ns }}$} \\
\hline $\mathrm{F}_{\text {fertilization }}$ & \multicolumn{2}{|c|}{$\begin{array}{c}7.32 * \\
(\text { Tukey }=14.9)\end{array}$} & \multicolumn{2}{|c|}{$1.32^{\mathrm{ns}}$} & \multicolumn{2}{|c|}{$1.50^{\mathrm{ns}}$} & \multicolumn{2}{|c|}{$1.99^{\mathrm{ns}}$} \\
\hline $\mathrm{F}_{\text {tillage } \times \text { fertilization }}$ & \multicolumn{2}{|c|}{$0.84^{\mathrm{ns}}$} & \multicolumn{2}{|c|}{$1.04^{\mathrm{ns}}$} & & & & \\
\hline 2013 & & & & & Dry we & $\left.\mathrm{kg} \mathrm{ha}^{-1}\right)$ & Seed y & $\left.\mathrm{g} \mathrm{ha}^{-1}\right)$ \\
\hline Control & 146 & 148 & 3.95 & 4.25 & 7970 & 7760 & 1960 & 1900 \\
\hline N1 & 162 & 160 & 4.50 & 4.75 & 8665 & 7970 & 2185 & 2260 \\
\hline $\mathrm{N} 2$ & 173 & 166 & 4.45 & 4.80 & 9125 & 9080 & 2380 & 2380 \\
\hline Manure & 161 & 154 & 4.35 & 4.60 & 9100 & 9020 & 2067 & 2185 \\
\hline $\mathrm{F}_{\text {tillage }}$ & & & & & & & & \\
\hline $\mathrm{F}_{\text {fertilization }}$ & (Tul & 4.4) & & & (Tuk & 021) & $\begin{array}{r}1 \\
\text { (Tuk }\end{array}$ & *2.9) \\
\hline $\mathrm{F}_{\text {tillage } \times \text { fertilization }}$ & & & & & & & & \\
\hline
\end{tabular}

Explanations: see Table 1 


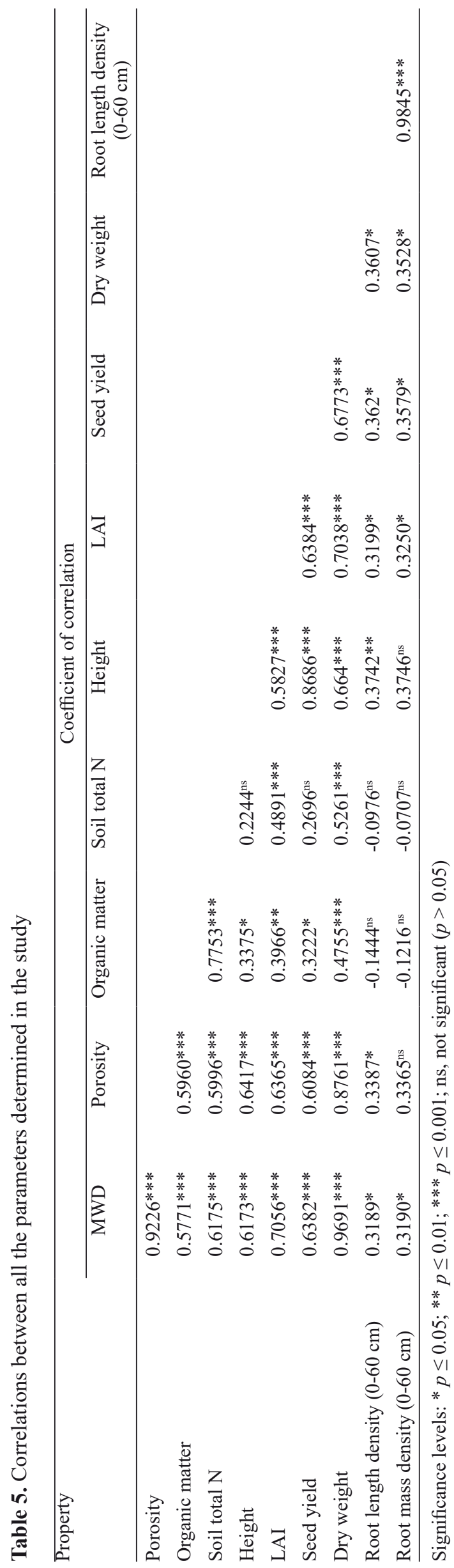

stimulating metabolic activity, which contributed to the increase in the amount of metabolites and consequently led to the elongation of internodes and increased plant height by increasing nitrogen levels (Shams, 2012; Geren, 2015). Because of the relatively considerable height of the plant, a high concentration of photosynthetic products was observed and a positive and significant correlation between plant height and dry weight was found $(r=$ $0.664, p<0.001)$.

\section{Leaf area index (LAI)}

The results of the present study indicated that the influence of tillage system on the leaf area index (LAI) was not significant. Despite the absence of significant effects of tillage system on LAI, and with the exception of the third year (2013), the plots subjected to the conventional tillage produced the highest values (4.66 and 4.50 in 2011 and 2012, respectively), while the lowest values (4.45 and 4.48 in 2011 and 2012, respectively) were obtained from the minimum tillage system (Tab. 4). This result is in accordance with previous findings of Bilalis et al. (2012). The effect of fertilization on LAI was also not significant; however, the highest values (4.63-4.70) were found in the case of the $\mathrm{N} 2(200 \mathrm{~kg}$ $\mathrm{N} \mathrm{ha}^{-1}$ ) treatment, confirming the positive response of quinoa crops to inorganic nitrogen fertilization (Jacobsen et al., 2005; Basra et al., 2014). Also, root length density has been found to be correlated with the nitrogen content of leaves and further growth of the leaf area of quinoa plants (Kammann et al. 2011). Such results were also observed in our experiment, with the coefficient of correlation $(r)$ being 0.320 $(p=0.027)$. The leaf area index exhibited a positive and significant correlation with root mass density $(r=0.325, p=0.024)$.

\section{Plant dry weight}

Concerning plant dry weight, the influence of the different tillage systems was found not to be statistically significant. Despite that, the study data showed that the highest values (8715-8969 $\left.\mathrm{kg} \mathrm{ha}^{-1}\right)$ were achieved in the conventional tillage plots. The combined analysis of variance (Tab. 6) revealed that only fertilization had a significant effect on this trait. Plant dry weight ranged from $8112 \mathrm{~kg}$ $\mathrm{ha}^{-1}$ to $8968 \mathrm{~kg} \mathrm{ha}^{-1}$ for all the years and treatments. Lower values were obtained without fertilization, while treatment $\mathrm{N} 2\left(9080-9125 \mathrm{~kg} \mathrm{ha}^{-1}\right)$ and that with manure (9020-9100 $\mathrm{kg} \mathrm{ha}^{-1}$ ) showed higher values of plant dry weight and were statistically significant in the third year (2013). Papastylianou 


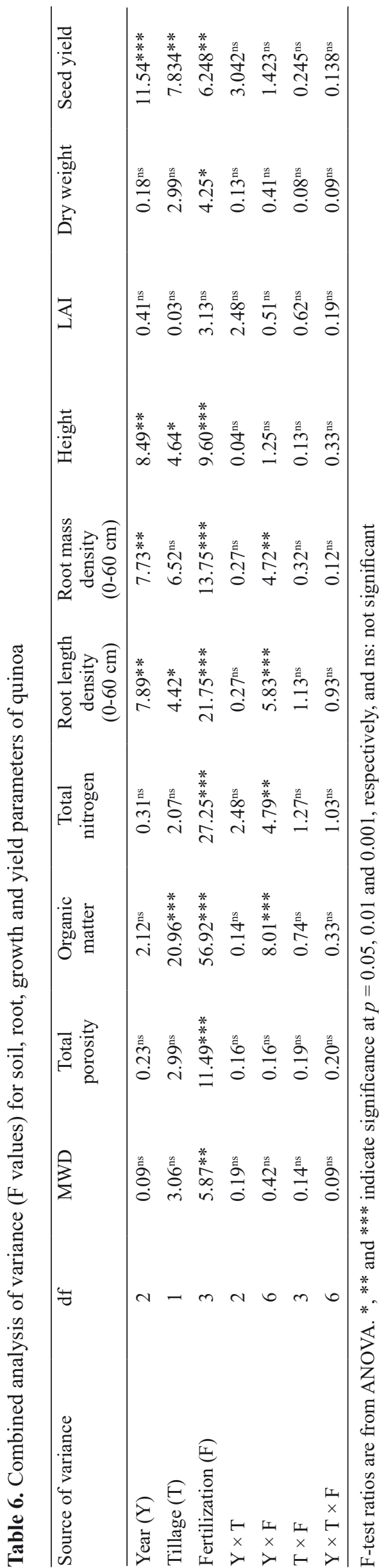

et al. (2014) had demonstrated a positive impact of organic fertilization on the dry matter yield of quinoa crops. The better growth development of the aboveground parts of the plant, especially of the leaf area, in combination with the higher nitrogen levels in the N2 treatment led to higher rates of photosynthesis and hence the highest dry weight. This relationship is also evidenced by the high correlation coefficient between plant dry weight and the leaf area index of the quinoa crop $(r=0.704$, $p<0.001)$. The relative soluble protein ratio, the carboxylase activity, and the chlorophyll and total nitrogen contents contribute to the increase in the rate of photosynthesis (Evans, 1983), and thus to the supply of the plant and seed with photosynthetic products.

\section{Seed yield}

According to the combined analysis (Tab. 6), seed yield was influenced by the tillage system and fertilization. Seed yield was greater in the conventional than in the minimum tillage plots during the first year (2011) (up to $2527 \mathrm{~kg} \mathrm{ha}^{-1}$ and $2306 \mathrm{~kg} \mathrm{ha}^{-1}$ for conventional and minimum tillage system, respectively). Limited data are available regarding the performance of quinoa grown under reduced tillage systems. Bilalis et al. (2012) stated that the highest seed yield was found under the minimum tillage system. Moreover, the seed yield in our study did not differ among the fertilization treatments in the first two years (2011 and 2012), but significant differences were found during the third year (2013), with the seed yields being 9103, 9060,8318 and $7865 \mathrm{~kg} \mathrm{ha}^{-1}$ for the application of $\mathrm{N} 2, \mathrm{~N} 1$, manure, and in the control, respectively. The results of our study revealed that seed yield was positively and linearly affected by the increase in nitrogen rates. In fact, quinoa responds well to nitrogen fertilization. Shams (2012) stated that the increase in the nitrogen fertilizer rate from 90 to $360 \mathrm{~kg} \mathrm{~N} \mathrm{ha}^{-1}$ increased the seed yield of quinoa from $518 \%$ to $1394 \%$ in comparison with the control $\left(0 \mathrm{~kg} \mathrm{~N} \mathrm{ha}^{-1}\right)$. Geren (2015) found that the application of nitrogen fertilizer at a rate of $150 \mathrm{~kg} \mathrm{~N} \mathrm{ha}^{-1}$ was recommended in order to obtain a high seed yield (2950 $\left.\mathrm{kg} \mathrm{ha}^{-1}\right)$, which was 357\% higher than that of the control $\left(0 \mathrm{~kg} \mathrm{~N} \mathrm{ha}^{-1}\right)$. The seed weight and yield are affected by the good development of the root system. Thangaraj et al. (1990) had reported that the root length density of lowland rice at the flowering stage was directly proportional to grain yield. Similarly, we obtained a statistically significant correlation between seed yield and root 
(A)

$$
\begin{gathered}
\text { Conventional Tillage }(C T) \\
\begin{aligned}
\text { Seed Yield }\left(\mathrm{kg} \mathrm{ha}^{-1}\right)=-201.0046+372.8779^{*} \mathrm{RLD}+526.5533^{*} \mathrm{LAl} \\
\mathrm{R}^{2}=0.5611 p=0.0002
\end{aligned}
\end{gathered}
$$

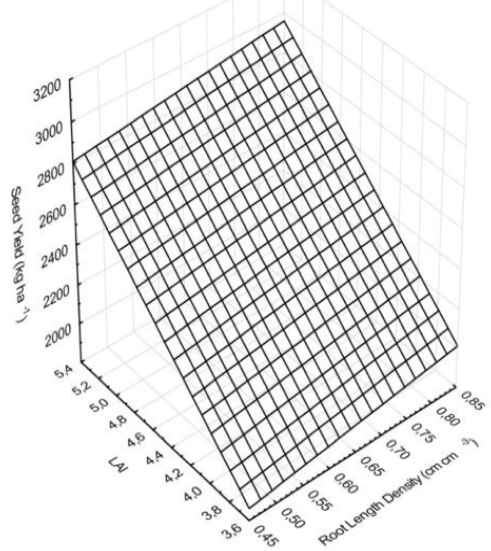

(B)

Minimum Tillage (MT)

Seed Yield $\left(\mathrm{kg} \mathrm{ha}^{-1}\right)=681.7706+547.7803^{*} \mathrm{RLD}+270.8604^{*} \mathrm{LAl}$ $R^{2}=0.4085 p=0.0040$

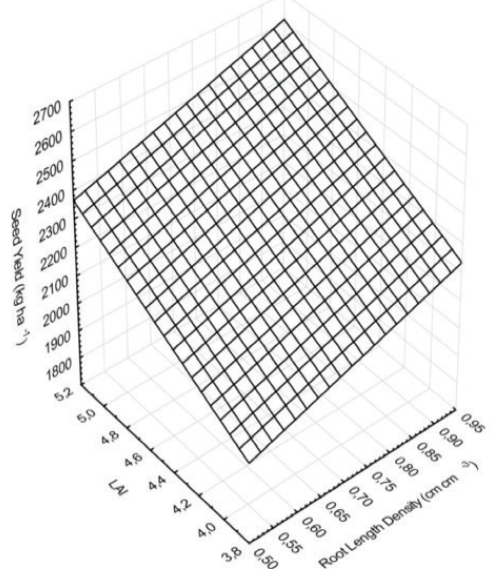

(C)
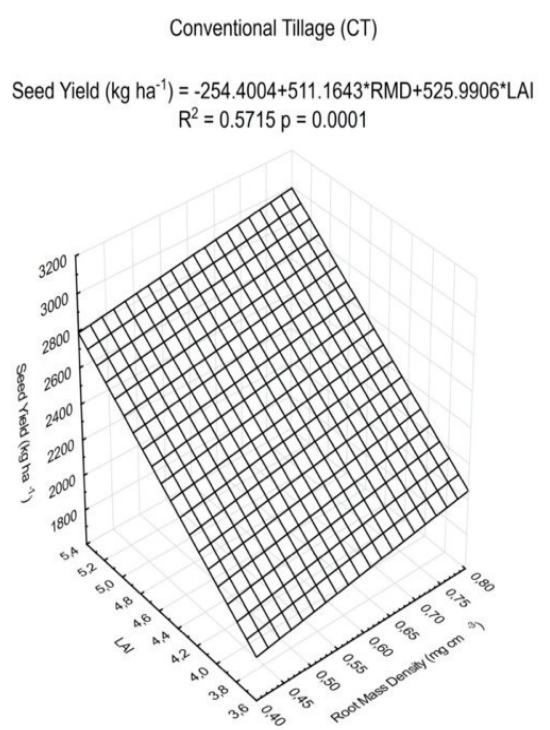

(D) Minimum Tillage (MT) Seed Yield $\left(\mathrm{kg} \mathrm{ha}^{-1}\right)=-787.2206+577.4282^{*} \mathrm{RMD}+249.3658^{*} \mathrm{LAl}$ $R^{2}=0.3935 p=0.0052$

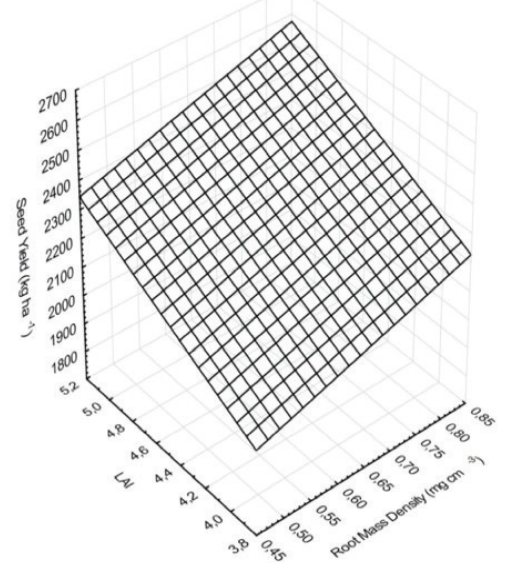

Figure 3. Multiple regression analysis between seed yield, leaf area index (LAI) and (A) root length density (RLD) $(0-60 \mathrm{~cm})$ for conventional tillage $(\mathrm{CT})$, (B) root length density (RLD) $(0-60 \mathrm{~cm})$ for minimum tillage (MT), (C) root mass density $(\mathrm{RMD})(0-60 \mathrm{~cm})$ for conventional tillage $(\mathrm{CT})$, and $(\mathrm{D})$ root mass density (RMD) $(0-60 \mathrm{~cm})$ for minimum tillage (MT)

length density $(r=0.362, p=0.0115)$, which is in full accordance with the study by Geren (2015). Seed yield exhibited a positive and significant correlation with root mass density $(r=0.358, p=$ $0.013)$. Also, leaf area was linearly correlated with seed yield $(r=0.638, p<0.001)$. This was due to the greater photosynthesis that led to the increase in photosynthetic products, improving both the dry weight and seed yield of the crop (Gomaa, 2013). The interactions of the leaf area index, root length density and root mass density with the seed yield of quinoa in this work, together with multiple regressions for the conventional and minimum tillage systems, are given in Figure 3. Finally, no interaction was found between fertilization and tillage system among the measurements in the present study.

\section{CONCLUSIONS}

The present results indicated that root growth and productivity of quinoa were significantly influenced by both the tillage system and fertilization. Mean weight diameter (MWD) of soil aggregates, total porosity, organic matter, and total nitrogen content of the soil increased with the long-term fertilization with sheep manure. The soil organic matter content was also influenced by the tillage system, and the greatest values were obtained in the soils 
subjected to conventional tillage, mainly due to the incorporation of plant residues in the soil. The major part of the roots of quinoa (approximately 70\%) was concentrated in the upper $0-30 \mathrm{~cm}$ soil layer. Root length density and root mass density increased with increasing rates of applied nitrogen. Additionally, the highest root mass density was observed under minimum tillage because this soil conservation system prevented intense soil perturbation. The leaf area index (LAI) was not influenced by tillage or fertilization. Plant height and dry weight were clearly affected by fertilization, with the higher values obtained with the higher rate of nitrogen fertilization $\left(200 \mathrm{~kg} \mathrm{~N} \mathrm{ha}^{-1}\right)$. Concerning the seed yield, the highest values were found in the plants cultivated under conventional tillage and treatment with $200 \mathrm{~kg} \mathrm{~N} \mathrm{ha}^{-1}$. To conclude, increasing the levels of applied nitrogen up to $200 \mathrm{~kg} \mathrm{~N} \mathrm{ha}$ improves root growth and consequently the yields of quinoa crops.

\section{FUNDING}

The research was supported by the Laboratory of Agronomy, Agricultural University of Athens.

\section{AUTHOR CONTRIBUTIONS}

All the authors contributed equally to the design and implementation of the research, to the analysis of the results and to the writing of the manuscript.

\section{CONFLICT OF INTEREST}

Authors declare no conflict of interest.

\section{REFERENCES}

Amgain L.P., Singh A.K., 2001. Effect of integrated nutrient management on physico-chemical properties of calciorthent and systems yield under rice-wheat system. J. Inst. Agric Anim. Sci. 21(22), 43-53.

Basra S.M.A., Iqbal S., Afzal I., 2014. Evaluating the response of nitrogen application on growth, development and yield of quinoa genotypes. Int. J. Agric. Biol. 16, 886-892.

Bhargava A., Shukla S., Ohri D., 2006. Chenopodium quinoa - An Indian perspective. Ind. Crop. Prod. 23, 73-87.

Bilalis D.J., Karkanis A., Papastylianou P., Patsiali S., Athanasopoulou M., Barla G., KaKabouki I., 2010. Response of organic linseed (Linum usitatissimum L.) to the combination of tillage systems, (minimum, conventional and no-tillage) and fertilization practices: Seed and oil yield production. Aust. J. Crop Sci. 4(9), 700-705.
Bilalis D., KaKabouki I., Karkanis A., Travlos I., Triantafyllidis V., Hela D., 2012. Seed and saponin production of organic quinoa (Chenopodium quinoa Willd.) for different tillage and fertilization. Not. Bot. Horti. Agrobot. Cluj-Napoca 40(1), 42-46.

Busari M.A., Salako F.K., 2015. Soil hydraulic properties and maize root growth after application of poultry manure under different tillage systems in Abeokuta, southwestern Nigeria. Arch. Agron. Soil Sci. 61, 223-237.

Costa C., Dwyer L.M., Zhou X., Dutilleul P., Hamel C., Reid L.M., Smith D.L., 2002. Root morphology of contrasting maize genotypes. Agron. J. 94, 96-101.

Daraghmeh O.A., Jensen J.R., Petersen C.T., 2009. Soil structure stability under conventional and reduced tillage in a sandy loam. Geoderma 150, 6471.

Drew M.C., 1975. Comparison of the effects of localized supply of phosphate, nitrate, ammonium, and potassium on the growth of the seminal root system and shoot of barley. New Phytol. 75, 470-490.

Evans J., 1983. Nitrogen and Photosynthesis in the Flag Leaf of Wheat (Triticum aestivum L.). Plant Physiol. 72, 297-302.

FAgERIA N.K., DOS SANTOS A.B., 2013. Lowland rice growth and development and nutrient uptake during growth cycle. J. Plant Nutr. 36, 1841-1852.

Flint A., Flint L.E., 2002. Particle density. In: Laboratory Methods, Methods of Soil Analysis, Part 4 - Physical Methods, SSA Book Series: 5. W.A. Dick (Ed.), SSSA, Madison, WI, USA, 229-240.

GARTON R.W., WidDERS I.E., 1990. $\mathrm{N}$ and $\mathrm{P}$ preconditioning of small plug seedlings influences growth and yield of processing tomatoes. HortScience 25, 655-657.

GEREN H., 2015. Effects of different nitrogen levels on the grain yield and some yield components of quinoa (Chenopodium quinoa Willd.) under Mediterranean climatic conditions. Turk. J. Field Crops 20, 59-64.

GomaA E.F., 2013. Effect of nitrogen, phosphorus and biofertilizers on quinoa plant. J. Appl. Sci. Res. 9, 5210-5222.

Gonzalez J.A., Konishi Y., Bruno M., Valoy M., PrADOC F.E., 2012. Interrelationships among seed yield, total protein and amino acid composition of ten quinoa (Chenopodium quinoa) cultivars from two different agro-ecological regions. J. Sci. Food Agric. 92, 1222-1229.

Goss M.J., KAY B.D., 2005. Soil aggregation. In: Roots and Soil Management: Interactions Between Roots and the Soil. R.W. Zobel and S.F. Wright (Eds), ASA, CSSA, and SSSA, Madison, WI, USA, 163-180.

Gregory P.J., 1994. Root growth and activity. In: Physiology and Determination of Crop Yield. G.A. Peterson (Ed.), ASA, CSSA, and SSSA, Madison, WI, USA, 65-93. 
Hansson A.C., Andren O., 1987. Root dynamics in barley, lucerne, and meadow fescue investigated with a minirhizotron technique. Plant Soil 103, 33-38.

JACOBSEN S.E., 2003. The worldwide potential for quinoa (Chenopodium quinoa Willd.). Food Rev. Int. $19,167-177$.

JACOBSEN S.E., JENSEN C.R., REDERSEN H., 2005. Use of the relative vegetation index for growth estimation in quinoa (Chenopodium quinoa Willd.). J. Food Agric. Environ. 3(2), 169-175.

Kakabouki I., Bilalis D., Karkanis A., Zervas G., TsiplaKou E., Hela D., 2014. Effects of fertilization and tillage system on growth and crude protein content of quinoa (Chenopodium quinoa Willd.): An alternative forage. Emir. J. Food Agric. 26(1), 18-24.

Kakabouki I.P., Hela D., Roussis I., Papastylianou P., Sestras A.F., Bilalis D.J., 2018. Influence of fertilization and soil tillage on nitrogen uptake and utilization efficiency of quinoa crop (Chenopodium quinoa Willd.). J. Soil Sci. Plant Nutr. 18(1), 220235.

Kammann C.I., Linsel S., Gössling J.W., Koyro H.W., 2011. Influence of biochar on drought tolerance of Chenopodium quinoa Willd. and on soil-plant relations. Plant Soil 345, 195-210.

Kokko E.G., Volkmar K.M., Gowen B., Entz T., 1993. Determination of total root surface area in soil core samples by image analysis. Soil Till. Res. 26, 33-43.

Kucharik C.J., Brye K.R., Norman J.M., Foley J.A., Gower S.T., Bundy L.G., 2001. Measurements and modeling of carbon and nitrogen cycling in agroecosystems of southern Wisconsin: Potential for SOC sequestration during the next 50 years. Ecosystems 4, 237-258.

LAL R., 1989. Conservation tillage for sustainable agriculture: tropics vs. temperate environments. Adv. Agron. 42, 85-197.

Meng L., Ding W., CAi Z., 2005. Long-term application of organic manure and nitrogen fertilizer on $\mathrm{N}_{2} \mathrm{O}$ emissions, soil quality and crop production in a sandy loam soil. Soil Biol. Biochem. 37, 20372045.

Merrill S.D., TanaKa D.L., Hanson J.D., 2002. Root length growth of eight crop species in haplustoll soils. Soil Sci. Soc. Am. J. 66, 913-923.
Osaki M., Shinano T., Matsumoto M., Zheng T., TADANO T. 1997. A root-shoot interaction hypothesis for high productivity of field crops. In: Plant Nutrition for Sustainable Food Production and Environment. T. Ando, K. Fujita, T. Mae, H. Matsumoto, S. Mori and J. Sekiya (Eds), Kluwer Academic Publishers, Dordrecht, The Netherlands, 669-674.

Pagliai M., Vignozzi N., Pellegrini S., 2004. Soil structure and the effect of management practices. Soil Till. Res. 79, 131-143.

Papastylianou P., Kakabouki I., Tsiplakou E., Travlos I., Bilalis D., Hela D., et al., 2014. Effects of fertilization on yield and quality of biomass of quinoa (Chenopodium quinoa Willd.) and green amaranth (Amaranthus retroflexus L.). Bulletin UASVM Horticulture 71(2), 287-292.

Sainju U.M., Singh B.P., Whitehead W.F., 2005. Tillage, cover crops, and nitrogen fertilization effects on cotton and sorghum root biomass, carbon, and nitrogen. Agron. J. 97, 1279-1290.

SHAMS A.S., 2012. Response of quinoa to nitrogen fertilizer rates under sandy soil conditions. Proc. $13^{\text {th }}$ Int. Conf. Agron., 9-10 September, Fac. of Agric., Benha Univ., Egypt, 195-205.

Sosa-Zuniga V., Brito V., Fuentes F., Steinford U., 2017. Phenological growth stages of quinoa (Chenopodium quinoa) based on the $\mathrm{BBCH}$ scale. Ann. Appl. Biol. 171, 117-124.

Thangaraj M., O’tolle J.C., De Datta S.K., 1990. Root response to water stress in rainfed lowland rice. Exp. Agric. 26, 287-296.

VAN BAVEL C.M., 1949. MWD of soil aggregates as a statistical index of aggregation. Soil Sci. Soc. Am. Proc. 14, 20-23.

Varvel G.E., Wilhelm W.W., 2010. Long-term soil organic carbon as affected by tillage and cropping systems. Soil Sci. Soc. Am. J. 74, 915-921.

ZHANG M.K., FANG L.P., 2007. Effect of tillage, fertilizer and green manure cropping on soil quality at an abandoned brick making site. Soil Till. Res. 93, 8793.

Received February 5, 2019; accepted July 23, 2019 